\title{
Pollen morphology of the subfamily Salicornioideae (Chenopodiaceae s.s.) in Eurasia and North Africa
}

\author{
Mehdi Dehghani $^{\mathrm{a} b}$, Morteza Djamali ${ }^{\mathrm{c}}$, Hossein Akhani ${ }^{\mathrm{a}^{*}}$ \\ ${ }^{a}$ Halophytes and $\mathrm{C}_{4}$ Plants Research Laboratory, Department of Plant Sciences, School of Biology, \\ College of Science, University of Tehran, 14155-6455 Tehran, Iran \\ ${ }^{b}$ Department of Biology, Faculty of Science, University of Zabol, Zabol, Iran \\ 'Institut Méditerranéen de Biodiversité et d'Ecologie (IMBE), Aix Marseille Univ, Avignon \\ Université, CNRS, IRD, Technopôle Arbois Méditerranée, Bât. Villemin - BP 80, F-13545, Aix-en- \\ Provence Cedex 04, France \\ *Corresponding author: hakhani@ut.ac.ir
}

\begin{abstract}
Pollen morphology of 40 specimens of 15 species belonging to eight genera in the subfamily Salicornioideae (Chenopodiaceae), was studied using Light (LM) and Scanning Electron Microscopy (SEM) to evaluate the taxonomic importance of pollen characters. Pollen grains were characteristically pantopolyporate with31-51 evenly distributed pores on the surface. Tectum and operculum are covered with minute spinules, typical of other members of Chenopodiaceae, with minor differences among different genera and species. Perforation was only seen in Halostachys belangeriana at high magnification. Pollen characters studied in this study include pollen and pore diameters, number and density of apertures, interporal distance (chord), chord/pollen diameter ratio, pore diameter/pollen diameter ratio as well as spinule density on tectum and operculum. Despite extreme uniformity in pollen morphology there is good evidence supporting currently known phylogenetic relationships and generic delimitations within the Salicornioideae subfamily. The significant differences in pollen characters among populations of Halostachys belangeriana and Halocnemum strobilaceum may indicate genetic diversity or polyploidy in different populations. The pollen characters provide limited taxonomic value in the Salicornioideae subfamily which may come from habitat homogeneity of all species growing in hypersaline marshes and inland hygrohalophytic communities.
\end{abstract}

Keywords: Amaranthaceae, Caryophyllales, Irano-Turanian region, Mediterranean region, palynology, pollen-habitat relationship.

\section{Introduction}

Chenopodiaceae s.s., includes 105 genera and 1400 to 1700 species (Hernández-Ledesma et al. 2015; Akhani et al. 2016), with worldwide distribution but most abundant in deserts, semi-deserts and saline soils in temperate and subtropical regions (Kühn et al. 1993; Zhu 1995; Kadereit et al. 2003). The family has been subjected to extensive molecular studies during the past two decades, representing one of the most phylogenetically well-known families in Caryophyllales with seven distinct subfamilies including Chenopodioideae, Betoideae, Corispermoideae, Salicornioideae, Suaedoideae, Camphorosmoideae and Salsoloideae (Kadereit et al. 2003; Akhani et al. 2007; Kadereit et al. 2010; Wen et al. 2010; Fuentes-Bazan et al. 2012). The inclusion of Chenopodiaceae in its closely related family Amaranthaceae has also been suggested by many morphological, serological and molecular studies (e.g. Malligson 1922; Judd et al. 2002; APG IV 2016) although there are some recently published studies considering them as two separate families with quite different global distributions and habitat preferences (Hernández-Ledesma et al. 2015). 
Salicornioideae subfamily is a monophyletic clade with 13 genera and about 100 species (Ball et al. 2017; Piirainen et al. 2017). The genera Allenrolfea Kuntze (three subshrub and shrubby species), Heterostachys C.A.Mey. ex Schrenk (two shrubby species) and the species Arthroceras subterminale (Parish) Piirainen \& G.Kadereit and Mangleticornia ecuadorensis P. W. Ball, G. Kadereit \& Cornejo (a relict shrubby species in Ecuador and Peru) are distributed restrictively in America. All 44 species of Tecticornia Hook f. (comprising nearly half of the species in the subfamily) are endemic to Australia except for Tecticornia indica (Willd.) K.A.Sheph. \& Paul G.Wilson which stretches along the tropical coasts of Asia and Africa and T. australasica in Northern Territory, Queensland and New Guinea. Salicornia L. (25-30 species) and Sarcocornia A.J.Scott (28 species) are distributed worldwide with eight and 11-15 representatives in Eurasia, respectively. Other genera including Arthrocaulon Piirainen \& G.Kadereit (two species), Halocnemum M.Bieb., (two species), Halopeplis Bunge ex Ung.-Sternb. (three species), Kalidium Moq. (six species), Halostachys belangeriana (Moq.) Botsch and Microcnemum coralloides (Loscos \& J. Pardo) Buen are mostly Eurasian (Kadereit et al. 2007; Shepherd and Wilson 2007; Steffen et al. 2010, 2015; Biondi et al. 2013; Sukhorukov and Nilova 2016; Ball et al. 2017; Piirainen et al. 2017). Altogether some 35 species are distributed in Eurasia and North Africa, of which 15, representing all genera of the region (except for Tecticornia indica), are included in this study.

The members of this subfamily are a group of hygro-halophyte plants with succulent and predominantly articulate stems, reduced leaves and inflorescences of spikelets comprised of minute reduced flowers (Kühn et al. 1993). These morphological modifications allow them to tolerate the harsh conditions of their habitats, especially high salinity and extreme physiological drought (Waisel 1972; Short and Colmer 1999), but at the same time cause many taxonomic problems due to a lack of morphological characteristics, leading chenopod researchers (Kadereit et al. 2007; Akhani 2008) to consider the genus Salicornia something of a nightmare!

The members of Salicornioideae subfamily form vast communities in coastal and inland saline soils (Akhani 2004) and play a major role in providing water and energy to wild and domestic animals in halophytic pastures. Some genera, such as Halostachys, Halocnemum and Kalidium with a high yield, are traditional fodder for livestock (Zhao and Feng 2001; Squires and Ayoub 2012); these genera are also known to accumulate $\mathrm{Na}^{+}$and $\mathrm{Cl}^{-}$in their tissues, harvest and removal of which might be a solution for soil desalinization (Zhao et al. 2002, 2005; Matinzadeh et al. 2013; Matinzadeh et al. 2019). In addition, there are many studies showing the potential medical uses of species of the Salicornioideae subfamily, including anti-oxidant and antimicrobial (Liu et al. 2010, 2012), anti-phytopathogenic (Hong-bing et al. 2009), and anti-diabetic (Bang et al. 2002) properties.

Salicornia seeds, with their unique lipid constitution, contain $25-30 \%$ oil and protein, comparable to those of soybean and cottonseed (Glenn et al. 1998), highly valuable not only for wildlife and domestic livestock but also a great potential source for oil production in highly saline soils where no glycophyte is able to grow. In addition, Salicornia shoots are edible and its seeds are of high nutritional value due to the presence of sulphur-rich proteins (Jha et al. 2012).

In palaeoecological studies using pollen as a hydroclimate proxy, high frequency of chenopod pollen is often interpreted as an aridity index (e.g. El-Moslimany 1987, 1990; Zhao and Herzschuh, 2009), causing inaccuracy in reconstructing past vegetation and climate since some chenopods, including members of Salicornioideae, are not characteristics of desertic and dry conditions but rather represent halophytic communities occupying humid saline soils (Dehghani et al. 2017). Distinction between halophytic and non-halophytic desertic species is thus of high importance in Quaternary palynological investigations (Djamali et al., 2008a). The family Chenopodiaceae is stenopolinous (Wodehouse 1935; Erdtman 1969; Lu et al. 2019), the pollen grains are monad and exclusively polypantoporate with tiny spinules on both tectum and operculum (Nowicke 1975; Skvarla and Nowicke 1976). There are a few comprehensive pollen morphological studies in Chenopodiaceae treating the whole family (Monoszon 1951, 1952; Dambach 1993), Suaedoideae (Dehghani and 
Akhani 2009) and Salsoloideae subfamilies (Toderich et al. 2010) and Atripliceae tribe (Olvera et al. 2006), resulting in important taxonomic, ecological and biological applications. Local studies focusing on pollen morphology of single or few genera of the family are also available (McAndrews and Swanson 1967; Uotila 1974; Perveen and Qaiser 2012). However, despite the ecological and taxonomical importance of the subfamily Salicornioideae, there is no detailed survey examining pollen morphology in this group.

In this study, we aim to evaluate the taxonomic importance of pollen morphology in reflecting phylogenetic relationships and delimiting genera and species of the subfamily Salicornioideae from Eurasia and North Africa.

\section{Materials and methods}

\section{Plant material and nomenclature}

Pollen morphology of 40 specimens of 15 species belonging to eight genera under the subfamily Salicornioideae was studied using Light (LM) and Scanning Electron Microscopy (SEM) (Table 2). The study covers all genera distributed in Asia, Europe and North Africa except for Tecticornia indica (due to lack of polliniferous material in accessible specimens). The material used in this study was obtained from herbarium samples deposited in the Halophytes and $\mathrm{C}_{4}$ Plants Research Laboratory, School of Biology, University of Tehran (Hb. Akhani), Université de Montpellier (MPU) and Muséum national d'histoire naturelle (P) (Appendix). The name of genera and species is based on latest accepted morpho-molecular concepts (Kadereit et al. 2006; Shepherd and Wilson 2007; Akhani 2008; Hernández-Ledesma et al. 2015; Piirainen et al. 2017), except for Sarcocornia in which we follow the classical circumscription of the genus Salicornia sensu Kühn et al. (1993) considering Sarcocornia as a separate genus.

\section{Light and scanning electron microscopy}

Polliniferous materials were treated using acetolysis technique (Erdtman 1969) in which the pollen bearing organs undergo six minutes treatment with acetolysis solution (one part concentrated sulphuric acid and nine parts acetic anhydride) in $90^{\circ} \mathrm{C}$ followed by centrifuging for five minutes in $3000 \mathrm{rpm}$ and washing with distilled water (for more details see Dehghani and Akhani 2009). Pollen grains were then mounted in glycerin jelly. Using a Nikon H III Ophtiphot-2 light microscope equipped with Motic Image Plus 2 software, 50 mature pollen grains were photographed at $\times 1000$ in two focal points; one at high focus to show exine surface structures, and the other at mid focus to show the exine structure. Pollen morphological data including pollen and pore diameters, chord distance (see below for definition) and exine thickness were measured using calibrated Motic Image Plus 2.0 software. Since pollen grains are geometrically spherical and pores are circular in shape, one each of the pollen-and pore diameters were measured as pollen and pore sizes respectively. Chord distance was obtained by measuring the distance between one edge of a pore and the opposite edge of neighboring pore. Other characters namely, number of pores, pollen grain area, pore area, pore density in $100 \mu^{2}$, pore diameter/pollen diameter ratio and chord/pollen diameter ratio (C/D) (McAndrews and Swanson 1967; Campbell 1992) were calculated in Excel software (Table 2). Pollen surface area is a function of pollen diameter and was calculated using the equation $\mathrm{SA}=4 \pi \mathrm{r}^{2}$, where SA is surface area and $r$ is the sphere radius, in order to calculate pore density on pollen surface. The nomenclature for description of the pollen morphology follows that of Erdtman (1966, 1969).

In order to prepare the samples for SEM studies, pollen grains were mounted on carbon pasted stubs and covered with $10 \mathrm{~nm}$ gold using a Magnetron Sputter Coater. At least three micrographs of the whole pollen grains and a surface close up micrograph at $\times 10000$ were taken for each sample with a Hitachi Su 3500 electron microscope (Central Laboratory at University of Shahid Beheshti, Tehran). 
The average density of spinules on $2 \mu \mathrm{m}^{2}$ of tectum area and the average number as well as density of spinules on operculum were counted and calculated based on three to five SEM observations. The visibility of perforations at $\times 10000$ magnification was also documented (Table2).

\section{Statistical analyses}

The means and standard deviations of all data were calculated using Microsoft Excel software. Pore number estimation was obtained according to the formula provided by Campbell (1992) in which the number of pore or any other evenly distributed objects on a spherical surface equals: $\mathrm{N}=540 /[\arcsin$ $(\mathrm{C} / \mathrm{D})]$ where $\mathrm{N}=$ number of pores, $\mathrm{C}=$ the distance between two adjacent pores and $\mathrm{D}=$ pollen diameter (Table 2).

Finally, a matrix of 40 specimens (samples) and 10 quantitative pollen grain characters (variables) was provided. Using Euclidian distances, the variation of pollen characters was investigated by Principle Component Analysis (PCA) in PAST V. 3.14 software (Hammer et al. 2001). Variancecovariance matrices were computed from which eigenvalue and eigenvector matrices were derived, based on which PCA biplot was extracted.

\section{Results}

The LM and SEM micrographs of eight genera and 15 species of Salicornioideae subfamily from Eurasia and N Africa are presented in Figs 1-4. Table 1 represents all studied species/populations in this study and their life forms, distribution ranges, Chorotypes and ecological types. Pollen grains in all studied samples of the subfamily are monad, pantopolyporate, tectate, spheroidal or subspheroidal in shape, with pores distributed evenly on the tectum. Tectum and operculum are covered with spinules, perforations are very minute and only in one case (Halostachys belangeriana) are visible at magnification of $10000 \times$. Pollen size averages of different species range from 18.16 to $36.13 \mu \mathrm{m}$ in diameter and average pore numbers vary from 31 to 51 in examined species of this subfamily. The means and standard deviations of pollen character measurements from light and electron microscopy are presented in Tables 2. A summary of pollen morphological results and important findings for each genus is also provided in the same table.

Arthrocaulon Piirainen \& G.Kadereit (=Arthrocnemum auct. non Moq.) (Fig. 1 A-B; Fig. 3 A-B). Pollen morphology of four accessions of the Eurasian and north African species, A. macrostachyum, studied by light microscopy, showed a continuous variation in terms of size, pore number and the distance between adjacent pores. Pollen diameter ranges from $24.30-27.52 \mu \mathrm{m}$, pore number varies from 35-44 and chord distance is between 5.88 and $7.11 \mu \mathrm{m}$ in four examined accessions (Table 2). According to electron microscopy images of the sample from Pakistan (Akhani 16531) average densities of spinules on operculum and on $2 \mu \mathrm{m}^{2}$ of tectum are 5 and 5.8 respectively, which are the lowest numbers compared to all other studied species in the subfamily (Table 2).

Halocnemum M. Bieb. (Fig. 1 C-D; Fig. 3 C-D). Four representatives of the widely distributed species Halocnemum strobilaceum were examined in this study. Pollen diameter in populations of this species ranges from 19.18 to $23.24 \mu \mathrm{m}$, pore number varies from 34-36, and chord distance is 5.04-6.08 $\mu \mathrm{m}$ (Table 2). The sample collected from Semnan (Akhani 24152) shows larger pollen with bigger pores, longer chord distance and thicker exine compared with the other three populations that show insignificant variations in pollen traits among them (Table 2). Pollen in this species shows the highest number of average spinules per $2 \mu \mathrm{m}^{2}$ of tectum area (16 spinules in $\left.2 \mu \mathrm{m}^{2}\right)$ in comparison with other studied species (Table 2).

Halopeplis Bunge ex Ung.-sternb. (Fig. 1 E-J; Fig. 3 E-H). All three species of the genus are included with six representatives, in our study. Pollen diameter in this genus ranges from 21.36$25.72 \mu \mathrm{m}$, pore number varies from 31 to 37 , and chord distance is 5.45-6.77 $\mu \mathrm{m}$ (Table 2). Pollen 
characters in studied populations of the genus Halopeplis display continuous variations with the exception of $H$. pygmaea (Akhani 24170) which shows larger pollen size (three micrometers bigger than other studied samples) (Table 2). The average densities of spinules on operculum and on $2 \mu \mathrm{m}^{2}$ of tectum for two studied species of this genus vary from 6.8 to 7.3 and 8.8 to 14.13 , respectively (Table 2).

Halostachys C. A. Mey. (Fig. 1 K-L; Fig. 3 I-J). Pollen morphology of seven populations of this monotypic Eurasian genus was studied here. There is a significant variation in pollen morphology of studied samples (Table 2, Fig 5). Pollen diameter in this genus ranges between 21.36 and $25.72 \mu \mathrm{m}$, pore number varies from 31 to 37, and chord distance is 5.45-6.77 $\mu \mathrm{m}$ (Table 2). In Of all samples of the subfamily Salicornioideae studied here by electron microscopy, only in one studied sample of $H$. belangeriana, are pollen perforations visible at magnification of $10000 \times$.

Kalidium Moq. (Fig. 1 M-P; Fig. 3 K-K; Fig. 4 A-B). Two out of five species of this Eurasian genus with four representatives were included in our study. Pollen diameter ranges from 18.16 to $22.90 \mu \mathrm{m}$, pore number varies between 32 and 37, and chord distance is 5.34-6.02 $\mu \mathrm{m}$ (Table 2). K. wagenitzii, an Anatolian endemic, shows the smallest pollen grain in the whole subfamily with the highest pore density. The two studied species are distinguishable based on pollen diameter $(18.16 \mu \mathrm{m}$ in $K$. wagenitzii and 20.15-22.90 $\mu \mathrm{m}$ in K. capsicum) and pore densities in $100 \mu \mathrm{m}^{2}$ of tectum $(3.07 \mathrm{in} K$. wagenitzii and 2.23-2.66 in K. capsicum). A population of K. capsicum (Akhani 24164) shows larger pollen size and a higher but overlapping pore number in contrast to the other two populations with highly similar pollen characters (Table 2).

Microcnemum Ung.-Sternb. (Fig. 1 Q-R; Fig. 4 C-D). This monotypic genus includes two disjunct subspecies in western areas of the Mediterranean region and western areas of the Irano-Turanian region (subp. coralloides from Spain and subsp. anatolicum from Iran), which show close pollen morphological characters. Pollen diameter is 25.31-25.91 $\mu \mathrm{m}$, pore number varies between 34 and 36 and chord distance ranges from 6.74 to $6.86 \mu \mathrm{m}$ (Table 2). In Microcnemum coralloides subsp. anatolicum both tectum and operculum of the pollen grains are densely occupied by spinules (Fig. 4, C-D, Table 2).

Salicornia L. (Fig. 1 S-T; Fig. 2 A-F; Fig. 4 E-j). Twelve specimens belonging to five species of this genus were investigated in this paper. Pollen diameter ranges from 22.21 to $27.88 \mu \mathrm{m}$, pore number varies between 38 and 46 and chord distance is 4.81-6.38 $\mu \mathrm{m}$ (Table 2). In agreement with close morphological similarities among various species of Salicornia, the pollen characters of different taxa do not show significant differences, making it impossible to distinguish any pollen type or group. (Fig. 5).

Sarcocornia A. J. Scott (Fig. 2 G-H; Fig. 4 K-L). The two studied populations of S. perennis in this paper show a significant difference in pollen diameter between them $(27.62$ versus $36.13 \mu \mathrm{m})$. Pollen in this genus represents the biggest pollen and pore sizes and the highest pore number on the tectum comparing to all other studied samples in the subfamily (Fig. 5).

Multivariate analysis

Fig. 5 shows the scatter plot of Principle Component Analysis (PCA) on pollen data measured under LM. The contributions of PCA axes 1 and 2 to the total variance are $67.99 \%$ and $27.11 \%$, respectively. The horizontal axis correlates with pore diameter and the vertical one is mainly associated with pore number. All studied accessions of Arthrocaulon macrostachyum are located at a relatively short distance from one another in the positive side of the PCA horizontal axis. Studied samples of Kalidium are also gathered together in the PCA diagram (Fig. 5). All species of Salicornia are placed on the negative side of the PCA horizontal axis and positive side of the PCA vertical axis, far away from two examined samples of its closely related genus, Sarcocornia. In 
Halocnemum only the sample collected from Semnan (Akhani 24152) stands distant from the other three samples in the PCA biplot. This is the case with the genus Halopeplis in which only a sample of Halopeplis pygmaea (Akhani 24170) is distant from its group (Fig. 5). The distribution of the seven samples of Halostachys is more interesting, as four samples are grouped together while other three samples are distributed on the other side of the diagram (Fig. 5).

\section{Discussion}

\section{Pollen grains provide monophyly and taxonomic signals}

Pollen morphology of all genera in the subfamily Salicornioideae distributed in Asia, Europe and North Africa studied in this research indicates a general uniformity of pollen grains in this subfamily. Similar results were obtained by Monoszon (1952) in a study on pollen grains of Chenopodiaceae growing in the former Soviet Union. In spite of a high degree of overlapping, the distribution of the different genera on the PCA biplot is in consensus with new taxonomic delimitations at genus level suggested by molecular evidence (Kapralov et al. 2006; Ball et al. 2017; Piirainen et al. 2017). In accordance with many morphological similarities among members of this subfamily, the variations and overlapping in pollen traits can be due to natural variation (plasticity) or genetic differences among different populations and various closely related taxa. Pollen morphological characters in the two subspecies of Microcnemum coralloides does not support recent morpho-molecular findings that suggest the two subspecies of M. coralloides (subsp. coralloides endemic of Iberian Peninsula and subsp. anatolicum, a SW Asian endemic) are genetically distinct taxa. In the case of Arthrocaulon macrostachyum there is not enough data on genetic variation of this widely distributed species, and therefore we can consider the distinction either as a reflection of genetic diversity among different taxa or natural variation among one species. It is interesting that despite the differing habit, habitat and geography of these two genera (Microcnemum as a small annual inland halophyte, but Arthrocaulon as a shrubby salt marsh plant), both phylogenetic results and pollen morphological data show their close affinity (Piirainen et al. 2017) (Fig.5). The similarity of seed protein profiles of three genera Microcnemum, Arthrocaulon and Sarcocornia (Yaprak and Yurdakulol 2007) is also supported by our PCA plot of pollen data (Fig.5). Moreover, the close phylogenetic affinities between Halocnemum and Halostachys (Kapralov et al. 2006; Ball et al. 2017; Piirainen et al. 2017) is also reflected by pollen morphological data (Fig. 5). On the other hand, the completely different distribution of Halostachys belangeriana populations (a monotypic genus) on our PCA diagram and the isolation of one specimen of Halocnemum strobilaceum (Akhani 24152) from other studied samples of this ditypic genus may indicate the presence of cryptic taxa in these genera, or the existance of local variation. Similarly, some cases have been observed in studied specimens of Halopeplis pygmaea and Kalidium caspicum which need to be studied if such variation in pollen morphology is related to any genetic difference or polyploidy variation (Fig. 5). Due to the succulent nature of many Chenopodiaceae, the interspecific differences between closely related species is often very difficult to assess, resulting in some discrepancy of species delimitation by different authors. An interesting case of such complexity was found in the formerly supposed monotypic genus Bienertia Bunge (Hedge 1997). Detailed studies on co-cultivation have revealed that the two species $B$. sinuspersici and B. kavirense can be distinguished further (Akhani et al. 2005, 2012).

In spite of continuous interspecific and intergeneric variations in pollen, all annual Salicornia specimens are grouped closely together in our PCA diagram (Fig. 5), indicating that pollen traits are consistent with the genetic proximity of the taxa, yet the separation of the species based on pollen characters is not feasible. Ghaffari et al. $(2006,2015)$ reported $S$. persica in central Iran as tetraploid $(2 n=4 x=36)$ and other examined taxa of Salicornia as Diploid $(2 n=2 x=18)$. However, there is no clear relationship between pollen traits in diploid and tetraploid species of Salicornia.

The noticeable pollen morphological differences between the two populations of Sarcocornia perennis can be attributed to the difference in ploidy levels; two chromosome numbers $(2 \mathrm{n}=18,36)$ 
have been reported for this species (Shepherd and Yan 2003). Therefore, it is likely that the Guillon 3895 specimen with the largest pollen grain in the whole subfamily is tetraploid but the Bouby 4951 specimen might be diploid, which causes the deviation in their distribution in the PCA diagram (Fig. 5). The pollen morphology data is not consistent with the assimilation of the perennial Sarcocornia into annual Salicornia, as has recently been proposed by molecular data (Steffen et al. 2010, 2015; Piirainen et al. 2017).

Pollen of Kalidium wagenitzii shows the smallest size in the whole subfamily, and is distinguishable from pollen of Kalidium caspicum based on pollen size and pore density (Table 2). These two species show significant morphological differences (Kadereit et al. 2006; Ball et al. 2017; Piirainen et al. 2017). In Kalidium wagenitzii, the leaves are tubular, while they are reduced in Kalidium caspicum and the stem is articulated. Due to these differences, Kalidium wagenitzii was originally described under the genus Kalidiopsis (Aellen 1967). The diversity centre of Kalidium is Central Asia, where four additional species are growing. Lu et al. (2019) described a Kalidium-pollen type among studied species of Chenopodiaceae from the eastern arid Central Asia which is characterized by the presence of isolated spines on pore membrane and pore diameter of 1-3.5 $\mu \mathrm{m}$. All

Salicornioideae species in this study fall into the same category of pore diameter. However, we did not consider the character of microechina on pore membrane in our study.

\section{Pore number and habitat moisture}

The application of pollen characters is limited in the taxonomy of the highly complicated groups under Salicornioideae. However, there are hints that indicate some pollen grain traits do correlate with habitat conditions. For example, in a study of pollen characters in the Suaedoideae subfamily it was found that very often higher numbers of pores are positively correlated with wet saline soils. Furthermore, it has been shown that $\mathrm{C}_{3}$ taxa in Suaeda Forssk. Ex J.F. Gmel. growing in wetter soils are characterized by higher pore numbers (Dehghani and Akhani 2009).

The most common pollen types in Angiospersms are monocolpate (in monocots) and tricolpate (in dicots). While exine provides protection for the pollen grains, apertures play three major roles including water and gas exchange with the environment, pollen tube germination and harmomegathy (Wodehouse 1935; Payne 1972). The last is a process in which pollen shape changes to adapt to the smaller or larger size of cytoplasm caused by dehydration or hydration (Wodehouse 1935; Punt et al., 2007) with apertures playing the most important role (Heslop-Harrison, 1979). Phylogenetically, the pantoporate pollen type is a derived form with at least 66 independent origins, occurring in 57 families of angiosperms particularly in the species of Caryophyllales (Prieu et al. 2017). Prieu et al. (2017) argue that pantoporate pollen distribution among angiosperms comes from positive short-term selection (such as accelerating water absorption and hence pollen germination) and negative longterm selection (for example the possibility of pollen desiccation during pollination) since this pollen type occurs frequently but with limited diversification and hardly fixed in large taxonomic groups. Multiple origins of pantoporate pollen is explained by the unique mechanism in which position and number of future apertures are determined by callose deposition (Albert et al. 2014) but reversion to the ancestral state is almost impossible (Matamoro-Vidal et al. 2016). The high rate of convergence in pantoporate pollen grains reflects the essential ecological determinism in the formation of this pollen type which may address the high similarity of pollen morphology in Salicornioideae species.

All members of the subfamily Salicornioideae are $\mathrm{C}_{3}$ species, except for some species of Tecticornia (not included in this study) (Shepherd and Wilson 2007; Voznesenskaya et al. 2008) occupying salt marshes, inland and saline soils around salt lakes and rivers, hence sharing a uniform pollen grain closely related to those of Chenopodioideae and the genus Suaeda (Monozson 1952; Uotila 1974; Dambach 1993; Akhani et al. 2003; Dehghani and Akhani 2009), but completely different from pollen of most members of the Salsoloideae subfamily, occupying more xeric habitats (Monozson 1951, 1952; Dambach 1993; Toderich et al. 2010; Authors unpublished data). A simple conclusion 
of these comparisons is that habitat moisture determines, to a large extent, the most taxonomically important character of chenopods' pollen grain, namely pore number. This finding can be very useful in interpreting fossil pollen to infer past vegetation and ecology of the earth, since pollen of Chenopodiaceae is one of the most predominant pollen grains in lake sediments in drylands of SW Asia (e.g. Wick et al. 2003; Djamali et al 2008b). In many studies, high frequency of Chenopodiaceae pollen has been interpreted as an aridity index but there are different types of chenopod pollen indicating different ecosystems and different soil hydroclogical conditions (Dehghani et al. 2017). We hypothesize that developing an operculum covered with increasing numbers of spinules and reducing the number of pores in the course of evolution may have been a strategy to reduce water loss during pollen transferring.

\section{Conclusions}

We conclude that pollen characters are of limited taxonomic value in Salicornioideae subfamily due to high similarity in pollen morphology, however, current taxonomic relationships and delimitations of the genera are relatively shown in multivariate analysis of pollen characters. It is likely that the uniformity of pollen characters in this subfamily comes from the similar ecological conditions in which the members of Salicornioideae grow. The pore number and possibly the presence of opercula and spinules may indicate the evolutionary responses to aridification in SW Asia. This last finding could shed light on paleoenvironmental interpretations of fossil pollen grains. A pollen type definition based on different pollen characters, especially the pore numbers and pore structure, may help to infer more precise environmental information from the Chenopodiaceae pollen which forms one of the most dominant components of fossil pollen assemblages in semi-arid regions of the world.

\section{Acknowledgments}

This paper is part of the $\mathrm{PhD}$ thesis of the first author which was supported by a scholarship from University of Zabol and an additional grant provided by the Iranian Ministry of Science and Technology for six months research in the Institut Méditerranéen de Biodiversité et d'Ecologie (IMBE), Aix Marseille Université, France. We are indebted to the curators of the Herbarium of Université de Montpellier, Caroline Loup, and Muséum national d'histoire naturelle in Paris, Dr Myriam Gaudeul, for their helps during the herbarium visit of M.D. We are also grateful to Saeed Javadi Anaghizi, technical assistant at the Central Laboratory of University of Shahid Beheshti, Tehran, for preparing SEM images of pollen grains. The costs of Scanning Electron Microscopy were granted by Iranian Science Elite Federation (ISEF) to H.A. The first author wishes also to thank the cultural service of the French Embassy in Tehran for their help and support in arranging the research stay in France. Finally, the linguistic editing of the text by Alison Rix (South Molton, UK) is much appreciated.

\section{Declaration of interest statement}

There is no conflict of interest

\section{References}

Aellen P. 1967. New Chenopodiaceae from Turkey. Notes Roy Bot Gard Edinburgh. 28:29-34.

Akhani H. 2004. Halophytic vegetation of Iran: towards a syntaxonomical classification. Ann Bot (Rome). 4:65-82.

Akhani H. 2008. Taxonomic revision of the genus Salicornia L. (Chenopodiaceae) in Central and Southern Iran. Pakistan J Bot. 40(4):1635-55. 
Akhani H, Barroca J, Koteeva N, Voznesenskaya E, Franceschi V, Edwards G, Ghaffari SM, Ziegler H. 2005. Bienertia sinuspersici (Chenopodiaceae): a new species from Southwest Asia and discovery of a third terrestrial $\mathrm{C}_{4}$ plant without Kranz anatomy. Syst Bot. 30(2):290-301.

Akhani H, Chatrenoor T, Dehghani M, Khoshravesh R, Mahdavi P, Matinzadeh Z. 2012. A new species of Bienertia (Chenopodiaceae) from Iranian salt deserts: a third species of the genus and discovery of a fourth terrestrial $\mathrm{C}_{4}$ plant without Kranz anatomy. Plant Biosyst. 146(3):550-559.

Akhani H, Edwards G, Roalson EH. 2007. Diversification of the Old World Salsoleaes.l.

(Chenopodiaceae): Molecular phylogenetic analysis of nuclear and chloroplast datasets and a revised classification. Int J Plant Sci. 168(6):931-956.

Akhani H, Ghobadnejhad M, Hashemi MH. 2003. Ecology, biogeography and pollen morphology of Bienertia cycloptera Bunge ex Boiss. (Chenopodiaceae), an enigmatic $\mathrm{C}_{4}$ plant without Kranz anatomy. Plant Biology. 5:103-214.

Akhani H, Khoshravesh R, Malekmohammadi M. 2016. Taxonomic novelties from Irano-Turanian region and NE Iran: Oreosalsola, a new segregate from Salsola s.1., two new species in Anabasis and Salvia, and two new combinations in Caroxylon and Seseli. Phytotaxa. 249(1):159-180.

Albert B, Toghranegar Z, Nadot S. 2014. Diversity and evolution of microsporogenesis in Bromeliaceae. Bot. J. Linean Soc. 176(1):36-45.

APG IV 2016. An update of the Angiosperm Phylogeny Group classification for the orders and families of flowering plants. Bot J Linn Soc. 181(1):1-20.

Ball P W, Cornejo X, Kadereit G. 2017. Mangleticornia (Amaranthaceae: Salicornioideae) - a new sister for Salicornia from the Pacific coast of South America. Willdenowia 47: 145 - 153.

Bang MA, Kim HA, Cho YJ. 2002. Hypoglycemic and antioxidant effect of dietary hamcho powder in streptozotocin-induced diabetic rats. J Korean Soc Food Sci Nutr. 31(5):840-6.

Biondi E, Casavecchia S, Estrelles E, Soriano P. 2013. Halocnemum M. Bieb. vegetation in the Mediterranean Basin. Plant Biosystems-An International Journal Dealing with all Aspects of Plant Biology. 147:536-547.

Campbell ID. 1992. Formula and nomogram for estimating the number of regularly patterned elements on the surface of a spheroidal microfossil. Rev Palaeobot Palyno. 72(1-2):165-167.

Dambach K. 1993. Die Palynologie der Chenopodiaceae-Kritische Bemerkungen zur Arbeit von Frau Monoszon [The palynology of the Chenopodiaceae: critical notes on the work of Ms. Monoszon] [Master's thesis]. Stuttgart (Germany): University of Hohenheim.

Dehghani M, Akhani H. 2009. Pollen morphological studies in subfamily Suaedoideae (Chenopodiaceae). Grana. 48(2):79-101.

Dehghani M, Djamali M, Gandouin E, Akhani H. 2017. A pollen rain-vegetation study along a $3600 \mathrm{~m}$ mountain-desert transect in the Irano-Turanian region; implications for the reliability of some pollen ratios as moisture indicators. Rev Palaeobot Palyno. 247:133-148.

Djamali M, Kürschner H, Akhani H, de Beaulieu JL, Amini A, Andrieu-Ponel V, Ponel P, Stevens L. 2008a. Palaeoecological significance of the spores of the liverwort Riella (Riellaceae) in a late 
Pleistocene long pollen record from the hypersaline Lake Urmia, NW Iran. Rev Palaeobot Palyno 152: 66-73.

Djamali M, de Beaulieu JL, Shah-Hosseini M, Andrieu-Ponel V, Amini A, Akhani H, Leroy SAG, Stevens L, Alizadeh H, Ponel P, Brewer S. 2008b. An Upper Pleistocene long pollen record from the Near East, the 100 m-long sequence of Lake Urmia, NW Iran. Quaternary Res. 69:413-420.

El-Moslimany AP. 1987. The late Pleistocene climates of the Lake Zeribar region (Kurdistan, western Iran) deduced from the ecology and pollen production of nonarboreal vegetation. Plant Ecol. 72(3):131-139.

El-Moslimany AP. 1990. Ecological significance of common nonarboreal pollen: examples from drylands of the Middle East. Rev Palaeobot Palyno. 64(1-4):343-350.

Erdtman G. 1966. Pollen morphology and plant taxonomy. Angiosperms. An introduction to palynology I. Hafner Publishing Co., New York and London.

Erdtman G. 1969. Handbook of palynology. morphology - taxonomy - ecology. an introduction to the study of pollen grains and spores. Copenhagen: Munksgaard.

Fuentes-Bazan S, Uotila P, Borsch T. 2012. A novel phylogeny-based generic classification for Chenopodium sensu lato, and a tribal rearrangement of Chenopodioideae (Chenopodiaceae). Willdenowia. 42:5-24.

Ghaffari SM, Ebrahimzadeh SRL, Akhani H. 2006. Chromosome numbers and karyotype analyses of species of subfamily Salicornioideae (Chenopodiaceae) from Iran. Iran. Journ. Bot. 12 (2):128-135.

Ghaffari SM, Balaei Z, Chatrenoor T, Akhani H. 2015. Cytology of SW Asian Chenopodiaceae: new data from Iran and a review of previous records and correlations with life forms and $\mathrm{C}_{4}$ photosynthesis. Plant Syst Evol. 301(2):501-521.

Glenn EP, Brown JJ, O’Leary JW. 1998. Irrigating crops with seawater. SciAm. 279(2):76-81.

Hammer Ø, Harper DAT, Ryan PD. 2001. PAST: Paleontological statistics software package for education and data analysis. Palaeomtol Elecronica. 4: 1-9

Hedge H. 1997. Salicornia L. - In Rechinger KH. editor. Flora Iranica Vol. 172. Graz (Austria): Akademische Druck- und Verlagsanstalt; p. 130-131

Hernández-Ledesma P, Berendsohn WG, Borsch Th, Mering SV, Akhani H, Arias S, Castañeda-Noa I, Eggli U, Eriksson R, Flores-Olvera H, Fuentes-Bazán S, Kadereit G, Klak C, Korotkova N, Nyffeler R., Ocampo G., Ochoterena H., Oxelman B., Rabeler R. K., Sanchez A., Schlumpberger BO, Uotila P. 2015. A taxonomic backbone for the global synthesis of species diversity in the angiosperm order Caryophyllales. Willdenowia. 45(3):281-383.

Heslop-Harrison J. 1979. An interpretation of the hydrodynamics of pollen. Am J Bot. 66(6): 737-743.

Hong-bing YA, Ya-ming ZH, Hao LI, Hua DU, Zhan-hong MA, Chun LI, Li-gang ZH. 2009. Inhibitory activity of extracts and fractions from six Chenopodiaceous Plants on plant pathogens. Nat Prod Res Dev. 21(5) 744-747. 
Jha B, Singh NP, Mishra A. 2012. Proteome profiling of seed storage proteins reveals the nutritional potential of Salicornia brachiate Roxb., an extreme halophyte. J Agr Food Chem. 60(17):4320-4326.

Judd WS, Campbell CS, Kellogg EA, Stevens PF, Donoghue MJ. 2002. Plant systematics: a phylogenetic approach. 2nd ed. Sunderland: Sinauer.

Kadereit G, Ball P, Beer S, Mucina L, Sokoloff D, Teege P, Yaprak AE, Freitag H. 2007. A taxonomic nightmare comes true: phylogeny and biogeography of glassworts (Salicornia L., Chenopodiaceae). Taxon. 56(4):1143-70.

Kadereit G, Borsch T, Weising K, Freitag H. 2003. Phylogeny of Amaranthaceae and Chenopodiaceae and the evolution of $\mathrm{C}_{4}$ photosynthesis. Int J Plant Sci. 164(6):959-986.

Kadereit G, Mavrodiev EV, Zacharias EH, Sukhorukov AP. 2010. Molecular phylogeny of Atripliceae (Chenopodioideae, Chenopodiaceae) Implications for systematics, biogeography, flower and fruit evolution, and the origin of $\mathrm{C}_{4}$ photosynthesis. Am J Bot. 97(10):1664-1687.

Kadereit G, Mucina L, Freitag H. 2006. Phylogeny of Salicornioideae (Chenopodiaceae): diversification, biogeography, and evolutionary trends in leaf and flower morphology. Taxon. 55(3):617-642.

Kapralov MV, Akhani H, Voznesenskaya EV, Edwards G, Franceschi V, Roalson EH. 2006. Phylogenetic relationships in the Salicornioideae/Suaedoideae/Salsoloideaesl (Chenopodiaceae) clade and a clarification of the phylogenetic position of Bienertia and Alexandra using multiple DNA sequence datasets. Syst Bot. 31(3):571-85.

Kühn U, Bittrich V, Carolin R, Freitag H, Hedge IC, Uotila P, Wilson PG. 1993. Chenopodiaceae. in Kubitzki K. editor. Families and genera of vascular plants. Vol 2. Berlin: Springer; 253-281.

Liu H, Mou Y, Zhao J, Wang J, Zhou L, Wang M, Wang D, Han J, Yu Z, Yang F. 2010. Flavonoids from Halostachys caspica and their antimicrobial and antioxidant activities. Molecules. 15(11):793345.

Liu H, Wang K, Zhao J, Wang M, Zhou L. 2012. Secondary metabolites from Halostachys caspica and their antimicrobial and antioxidant activities. Rec Nat Prod. 6(1):57-61.

Lu KQ, Li M, Wang GH, Xu LS, Ferguson DK, Trivedi A, Xuan J, Feng Y, Li JF, Xie G, Yao YF, Wang YF. 2019. New pollen classification of Chenopodiaceae for exploring and tracing desert vegetation evolution in eastern arid central Asia. J Syst Evol. 57: 190-199.

Malligson F. 1922. Serodiagnostische Untrersuchungen über die Verwandtschaften innerhalb des Centrospermen-Astes des Pflanzenreiches. Bot Arch. 1:2-20. German.

Matinzadeh Z, Breckle S.-W., Mirmassoumi, M., Akhani H. 2013. Ionic relationships in some halophytic Iranian Chenopodiaceae and their rhizospheres. Plant Soil. 372: 523-539.

Matinzadeh Z, Akhani H, Abedi M, Palacio S. 2019. The elemental composition of halophytes correlates with key morphological adaptations and taxonomic groups. Plant Physiol Bioch 141, 259278.

Matamoro-Vidal A, Prieu C, Furness CA, Albert B, Gouyon PH. 2016. Evolutionary stasis in pollen morphogenesis due to natural selection. New Phytol. 209(1):376-394. 
McAndrews JH, Swanson AR. 1967. The pore number of periporate pollen with special reference to Chenopodium. Rev Palaeobot Palyno. 3:105-117.

Monoszon MKh. 1951. [Morphology of the pollen grains of the family Chenopodiaceae. Trudy Instituta. Geografii.50: 142-166. Russian.

Monoszon MKh. 1952. Description of the pollen grains of the species of the family Chenopodiaceae growing on the territory of the U.S.S.R. Trudy Instituta Geografii 52:127-196. Russian.

Nowicke JW. 1975. Pollen morphology in the order Centrospermae. GRANA. 15:51-77.

Olvera HF, Fuentes-Soriano S, Hernández EM. 2006. Pollen morphology and systematics of Atripliceae (Chenopodiaceae). Grana. 45(3):175-194.

Perveen A, Qaiser M. 2012. Pollen flora of Pakistan- LXX: Chenopodiaceae. Pakistan J Bot. 44(4):1325-1333.

Piirainen M, Liebisch O, Kadereit G. 2017. Phylogeny, biogeography, systematics and taxonomy of Salicornioideae (Amaranthaceae/Chenopodiaceae)-A cosmopolitan, highly specialized hygrohalophyte lineage dating back to the Oligocene. Taxon.66:109-132.

Prieu C, Sauquet H, Gouyon PH, Albert B. 2017. More than sixty origins of pantoporate pollen in angiosperms. Am. J. Bot. 104(12):1837-1845.

Punt W, Hoen PP, Nilsson S, Le Thomas A. 2007. Glossary of pollen and spore terminology. Rev Palaeobot Palyno. 143(1-2): 1-81.

Shepherd KA, Wilson PG. 2007. Incorporation of the Australian genera Halosarcia, Pachycornia, Sclerostegia and Tegicornia into Tecticornia (Salicornioideae, Chenopodiaceae). Aust Syst Bot. 20(4):319-331.

Shepherd KA,Yan G. 2003. Chromosome number and size variations in the Australian Salicornioideae (Chenopodiaceae)—evidence of polyploidisation. Aust J Bot. 51(4):441-452.

Short DC, Colmer TD. 1999. Salt tolerance in the halophyte Halosarcia pergranulata subsp. pergranulata. Ann Bot. 83(3):207-13.

Skvarla JJ, Nowicke JW. 1976. Ultrastructure of pollen exine in centrospermous families. Plant Syst Evol. 126:55-78.

Squires V, Ayoub AT, editors. 2012. Halophytes as a resource for livestock and for rehabilitation of degraded lands. Springer Science \& Business Media.

Steffen S, Mucina L, Kadereit G. 2010. Revision of Sarcocornia (Chenopodiaceae) in South Africa, Namibia and Mozambique. Syst Bot. 35(2):390-408.

Steffen S, Ball P, Mucina L, Kadereit G. 2015. Phylogeny, biogeography and ecological diversification of Sarcocornia (Salicornioideae, Amaranthaceae). Ann. Bot. 115(3):353-368.

Sukhorukov AP, Nilova MV. 2016. A new species of Arthrocnemum (Salicornioideae:

Chenopodiaceae-Amaranthaceae) from West Africa, with a revised characterization of the genus. Botany Lett.163:237-250. 
Toderich KN, Shuyskaya EV, Ozturk M, Juylova A, Gismatulina L. 2010. Pollen morphology of some Asiatic species of genus Salsola (Chenopodiaceae) and its taxonomic relationships. Pakistan J Bot. 42:155-174.

Uotila P. 1974. Pollen morphology in European species of Chenopodium sect. Chenopodium with special reference to C. album and C. suecicum. Ann Bot Fenn. 11:44-58.

Voznesenskaya EV, Akhani H, Koteyeva NK, Chuong SD, Roalson EH, Kiirats O, Franceschi VR, Edwards GE. 2008. Structural, biochemical, and physiological characterization of photosynthesis in two $\mathrm{C}_{4}$ subspecies of Tecticornia indica and the $\mathrm{C}_{3}$ species Tecticornia pergranulata (Chenopodiaceae). J Exp Bot. 59(7):1715-1734.

Waisel Y.1972. Biology of halophytes. New York and London: Academic Press.

Wen ZB, Zhang ML, Zhu GL, Sanderson SC. 2010. Phylogeny of Salsoleae s.1. (Chenopodiaceae) based on DNA sequence data from ITS, $p s b B-p s b H$, and $r b c L$, with emphasis on taxa of northwestern China. Plant Syst Evol. 288(1-2):25-42.

Wick L, Lemcke G, Sturm M. 2003 Evidence of Late glacial and Holocene climatic change and human impact in eastern Anatolia: high-resolution pollen, charcoal, isotopic and geochemical records from the laminated sediments of Lake Van, Turkey. The Holocene. 13(5):665-75.

Wodehouse RP. 1935. Pollen grains: their structure identification and significance in science and medicine. New York and London: McGraw - Hill book company, INC.

Yaprak A, Yurdakulol E. 2007. Seed protein variations of Salicornia L. and allied taxa in Turkey. Pakistan J Biol Sci. 10:1930-1933.

Zhao K, Fan H, Jiang XY, Song J. 2002. Improvement and utilization of saline soil by planting halophytes. Chin J Appl Environ Biol. 8(1):31-5.

Zhao KF, Feng LT. 2001. Resources of halophytes in China. Beijing: China Science Press.

Zhao KF, Fan H, Song J, Sun MX, Wang BZ, Zhang SQ, Ungar IA. 2005. Two Na+ and Clhyperaccumulators of the Chenopodiaceae. J Integr Plant Biol. 47(3):311-8.

Zhao Y, Herzschuh U. 2009. Modern pollen representation of source vegetation in the Qaidam Basin and surrounding mountains, north-eastern Tibetan Plateau. Veg Hist Archaeobot. 18(3):245-260.

Zhu GL. 1995. Origin, differentiation, and geographic distribution of the Chenopodiaceae. Acta Phytotaxon Sin. 34:486-504.

Appendix:

Supplementary Internet Material: List of plant vouchers studied in this paper and the herbaria in which the vouchers are deposited

Arthrocaulon macrostachyum (Moric.) K. Koch. Greece: in Rhodo, Karpathos, Samos et AsiaMinore, auspice, 4-8.1886, W. Barbey 551, (MPU). 
Arthrocaulon macrostachyum (Moric.) K. Koch. Morocco: Terrains marecageux, pres du canal de fuite de la station de pompage de l'ile de Skrouna, dans lle Chott Chergui, 22.4.1952, A. Dubuis, (MPU).

Arthrocaulon macrostachyum (Moric.) K. Koch. Pakistan: Baluchestan, ca. $40 \mathrm{~km}$ NW of Karachi,

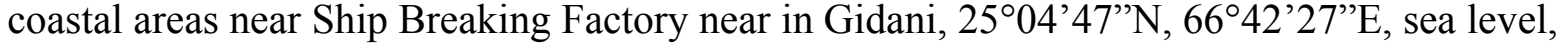
28.2.2003, H. Akhani 16536 (Hb. Akh.).

Arthrocaulon macrostachyum (Moric.) K. Koch. Pakistan: Sind, W of Karachi, mangroves and halophytic vegetation along the Arabian Sea coast, 24 50'50' 'N, 66 53'37' 'E, sea level, 28.2.2003, H. Akhani 16531 (Hb. Akh.).

Halocnemum strobilaceum (Pall.) M. Bieb. Iran: Bushehr $11 \mathrm{~km} \mathrm{NE}$ of Borazjan towards Kazeroun, saline soils, c. 100 m, 20.11.1991, H. Akhani 7955 (Hb. Akh.).

Halocnemum strobilaceum (Pall.) M. Bieb Turkey: Aksaray, $10 \mathrm{~km}$ E of Eskil towards southern saline shores of Tuz Gölü lake, high salty soils, $38^{\circ} 25^{\prime} 5^{\prime}$ ' $\mathrm{N}, 33^{\circ} 29^{\prime} 52^{\prime}$ 'E, 914 m, 28.8.2004, H. Akhani et al. 18004 (Hb. Akh.).

Halocnemum strobilaceum (Pall.) M. Bieb. Iran: Semnan, $67 \mathrm{~km}$ W Damghan in the road towards Cheshmeh Ali, high saline soils, $1822 \mathrm{~m}, 36^{\circ} 6^{\prime} 19^{\prime}$ 'N, 5347'27' 'E, 14.7.2001, H. Akhani and M. Salimian 15330 (Hb. Akh.).

Halocnemum strobilaceum (Pall.) M. Bieb. Iran: Semnan, Between Eivanakey and Semnan, $10 \mathrm{~km}$

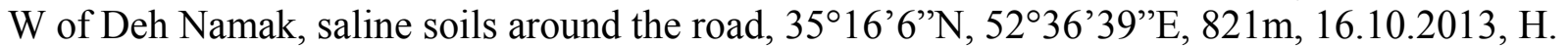
Akhani 24152 (Hb. Akh.).

Halopeplis amplexicaulis (Vahl) Ung.-Sternb. ex Ces., Pass. \& Gibelli. Algeria: Southern edge of Sebkha Ben Ziane, close to Ferry, Relizane Region, 15.5.1949, A. Dubuis, (MPU).

Halopeplis amplexicaulis (Vahl) Ces. \& al. Spain: Alicante, Blche, Laguna del Hondo, 30SXH9730. Halonitrophilous therophytic communities, 23.6.1984, D. Sanchez-Mata \& R. Gavilan 57 (MPU).

Halopeplis perfoliata (Forssk.) Asch. Iran: Hormozgan, Jask, saline wastelands along the road, $25^{\circ} 40^{\prime} 24^{\prime}$ 'N, 57 49'3'’E, ca. 10m, 27.11.2005, H. Akhani et al. 18337 (Hb. Akh.).

Halopeplis pygmaea (Pall.) Bunge ex Ung.-Sternb. Iran: Fars, N Tashk lake, high salty soils near Gomban, 294'시 $53^{\circ} 28^{\prime} \mathrm{E}, 1590$ m, 20.9.2001, Akhani \& Ghobadnejhad 15717 (Hb. Akh.).

Halopeplis pygmaea (Pall.) Bunge ex Ung.-Sternb. Iran: Semnan, Touran National Park, $50 \mathrm{~km}$ E of Biarjomand towards Ahmadabad, Kal Shur, saline soils around the river, $35^{\circ} 53^{\prime} \mathrm{N}, 56^{\circ} 19^{\prime} \mathrm{E}$, 806m, 17.0.2013. H. Akhani 24170 (Hb. Akh.).

Halopeplis pygmaea (Pall.) Bunge ex Ung.-Sternb. Iran: Tehran, E of Heuze Soltan Lake, 850 m, 18.9.1987, Akhani 5824 (Hb. Akh.).

Halostachys belangeriana (Moq.) Botsch. Iran: Arak, $27 \mathrm{~km}$ after Delijan towards Esfahan Road, 4.8.2005, M. Dehghani and A.A. Dolatyari 353 (Hb. Akh.). 
Halostachys belangeriana (Moq.) Botsch. Iran: E Azarbaijan Province, Southern saline flats of Lake Urmia, 10 km NW of Tappeh Rash, 378'27'N, 4545'17'E, 1297m, 27.6.2014, H. Akhani 24324 (Hb. Akh.).

Halostachys belangeriana (Moq.) Botsch. Iran: Khorassan, Between Mashhad and Sarakhs, $18 \mathrm{~km}$ after Mazdavand to Sarakhs, 650 m, 16.8.1994, Akhani and Zangui 10055 (Hb. Akh.).

Halostachys belangeriana (Moq.) Botsch. Iran: Khorassan, Rude Shur (salty river), $5 \mathrm{~km} \mathrm{~S}$. Sabzevar, salty and sandy soils, $36^{\circ} 09^{\prime} 32^{\prime}$ 'N, 57 $38^{\prime} 22^{\prime}$ 'E, $925 \mathrm{~m}, 20.7 .2001$, Akhani \& Salimian 15434 (Hb. Akh.).

Halostachys belangeriana (Moq.) Botsch. Iran: Semnan, Between Eivanakey and Semnan, $10 \mathrm{~km}$

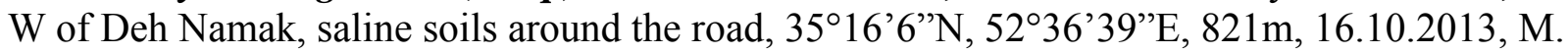
Dehghani 7118 (Hb. Akh.).

Halostachys belangeriana (Moq.) Botsch. Iran: Tehran, E. of Hueze-Soltan Lake, 800 m, 18.9.1987, Akhani 4760 (Hb. Akh.).

Halostachys belangeriana (Moq.) Botsch. Turkmenistan: Balkhan Province (= Krasnovodskayaoblasti), ca. $20 \mathrm{~km} \mathrm{NW}$ of Nebet- Dagh, near Mollakara, salty and sandy substrate margin of Uzboy river, ca. sea level, 10.9.1994, Akhani 10086-T (Hb. Akh.).

Kalidium capsicum (L.) Ung -Sternb.Iran: Gorgan, South of Golestan Natinal Park, 7 km W. of

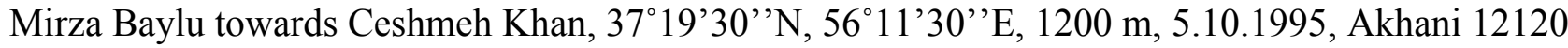
(Hb. Akh.).

Kalidium capsicum (L.) Ung -Sternb.Iran: Semnan, $23 \mathrm{~km} \mathrm{W.} \mathrm{of} \mathrm{Cheshmeh} \mathrm{Ali} \mathrm{towards}$ Shurtangeh (salty valley), halophytic communities on salt flats around salty river dominated by Tamarix, 36 10'50' N, 5353'51'’E, 1733 m, 15.11.2002, Akhani 16500 (Hb. Akh.).

Kalidium capsicum (L.) Ung -Sternb. Iran: Semnan, Touran National Park, $50 \mathrm{~km}$ E of Biarjomand towards Ahmadabad, Kal Shur, saline soils around the river, $35^{\circ} 53^{\prime} \mathrm{N}, 56^{\circ} 19^{\prime} \mathrm{E}, 806 \mathrm{~m}$, River water $\mathrm{EC}=43.3 \mathrm{~ms} / \mathrm{d}, 17.0 .2013$, H. Akhani 24164 (Hb. Akh.).

Kalidium wagenitzii(Aellen) Freitag \& G. Kadereit; Turkey: Aksaray, 10 k E of Eskil towards

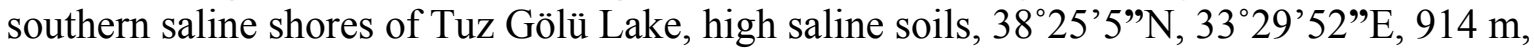
28.8.2004, H. Akhani et al. 18001 (Hb. Akh.).

Microcnemum coralloides (Loscos\& J. Pardo) Buen subsp anatolicum Wagenitz; Iran: East Azarbaijan Province, Eastern shores of Lake Urmia, saline wetland near mines located in $15 \mathrm{~km} \mathrm{SW}$ of Azarshahr, partly dominated by Juncus heldreichianus and partly disturbed grazd land, 3742’22’'N, 4550’37’'E, 1307m, 26.6.2014, H. Akhani 24319 (Hb. Akh.).

Microcnemum coralloides (Loscos\& J. Pardo) Buen subsp. coralloides; Spain: Cfr. Series in confecta flantarum, Aragonia. Habitat in salsuginoni humidis, Velsiesi, regionis inferioris Aragonia (Sierra- baja), lecta in Govea la saladata juxta viam inter Castel-sera et Andorra, 6-9.1872 Socius Lores et Bernal, (MPU).

Salicornia iranica Akhani subsp. iranica Iran: Fars, N. Tashk lake, high salty soils near Gomban, $29^{\circ} 48^{\prime} \mathrm{N}, 23^{\circ} 28^{\prime} \mathrm{E}, 1590 \mathrm{~m}, 20.9 .2001$, Akhani \& Ghobadnejhad 15721 (Hb. Akh.). 
Salicornia iranica subsp. rudshurensis (Akhani) Chatrenoor \& Akhani (ined.); Iran: Tehran, ca. $60 \mathrm{~km}$ W Tehran, Mardabad salt flats, 3543'4’N, 5044’24’'E, 1169 m, 10.10.2013, Akhani 17319, (Hb. Akh.).

Salicornia persica Akhani; Iran: Esfahan, Varzaneh, Zayand-e- rud river bed, 32²5'32'N, 52³9’05'’E, 1493 m, 16.9.2001, Akhani \& Ghobadnejhad 15667 (Hb. Akh.).

Salicornia persica Akhani Iran: Esfahan, Varzaneh, Zayand-e- rud river bed, $32^{\circ} 25^{\prime} 32^{\prime \prime}$ N, 52³9’05'’E, 1493 m, 16.9.2001, Akhani \& Ghobadnejhad 15671 (Hb. Akh.).

Salicornia persica Akhani Iran: Esfahan, Varzaneh, Zayand-e- rud river bed, $32^{\circ} 25^{\prime} 32^{\prime}$ 'N, 52³9'05'’E, 1493 m, 16.9.2001, Akhani \&Ghobadnezhad 15670, (Hb. Akh.).

Salicornia persica Akhani Iran: Fars, N Tashk lake, high salty soils near Gomban, $29^{\circ} 48^{\text {'N }}$, $23^{\circ} 28^{\prime} \mathrm{E}, 1590 \mathrm{~m}, 20.9 .2001$, Akhani \& Ghobadnejhad 15720 (Hb. Akh.).

Salicornia persica subsp. rudshurensis Akhani; Iran: Tehran, ca. $60 \mathrm{~km}$. W. Tehran, Mardabad salt flats, $35^{\circ} 43^{\prime} 40 \mathrm{~N}, 50^{\circ} 4424 \mathrm{E}, 1169$ m., 24.10.2003, Akhani 17423, (Hb. Akh.)

Salicornia procumbens Sm. South England: Lime Regis, Sea level, 20.8.2006, H. Akhani 18494, (Hb. Akh.).

Salicornia sp.; Turkey Konya, W of Tuz lake, $11 \mathrm{~km}$ SE of Cihanbeyli towards Tereskan, Alkim factory (Alkim Alkali kymia), 3333'13' 'N, 3255'45' 'E, 945 m, 28.8.2004 H. Akhani, E. Dogan, M. Ekici, M. Ghasemkhani 18020 (Hb. Akh.).

Salicornia sp.; Turkey: Konya, W of Tuz lake, $11 \mathrm{~km}$ SE of Cihanbeyli towards Tereskan, Alkim factory (Alkim Alkali kymia), 3333'13' 'N, 32 ${ }^{\circ} 55^{\prime} 45^{\prime}$ ' E, 945 m, 28.8.2004, H. Akhani et al. 18019 (Hb. Akh.).

Salicornia x tashkensis Akhani; Iran: Fars, N. Tashk lake, high salty soils near Gomban, 2948’N, $23^{\circ} 28^{\prime} \mathrm{E}, 1590 \mathrm{~m}, 20.9 .2001$, Akhani \& Ghobadnejhad 15722 (Hb. Akh.).

Sarcocornia perennis (Mill.) Scott; France: Province 17 Charente-Maritime, Fouras (CharenteMaritime), Plage de l'Espérance, 27.7.1960, H. Bouby 4951 (P05159478) (P).

Sarcocornia perennis (Mill.) Scott.; France: Salt marshes in Fouras (the area of lower Charente), 25.8.1867, A. Guillon 3895 (MPU). 
Table 1. List of studied species and their distribution and their phytogeography or chorotype (ES=Euro-Siberian, IT=Irano-Turanian, $\mathrm{M}=$ Mediterranean, $\mathrm{SS}=$ Saharo-Sindian), and habitats

\begin{tabular}{|c|c|c|c|c|}
\hline Species name & Life form & Distribution & Chorotype & Habitat \\
\hline $\begin{array}{l}\text { Arthrocaulon macrostachyum } \\
\text { (Moric.) K. Koch. }\end{array}$ & Chamaephyte & $\begin{array}{l}\text { Eurasia and northern } \\
\text { Africa }\end{array}$ & SS, M & Hygrohalophyte \\
\hline $\begin{array}{l}\text { Halocnemum strobilaceum } \\
\text { (Pall.) M. Bieb. }\end{array}$ & Chamaephyte & $\begin{array}{l}\text { S Mediterranean, SW and } \\
\text { C Asia }\end{array}$ & IT $(\mathrm{ES}, \mathrm{M})$ & Hygrohalophyte \\
\hline $\begin{array}{l}\text { Halopeplis amplexicaulis } \\
\text { (Vahl) Ces. \& al. }\end{array}$ & Annual & S Europe, N. Africa & $\mathrm{M}$ & Hygrohalophyte \\
\hline $\begin{array}{l}\text { Halopeplis perfoliata (Forssk.) } \\
\text { Asch. }\end{array}$ & $\begin{array}{l}\text { Hemicryptoph } \\
\text { yte }\end{array}$ & S Europe, N. Africa & SS. M & Hygrohalophyte \\
\hline $\begin{array}{l}\text { Halopeplis pygmaea (Pall.) } \\
\text { Bunge ex Ung.-Sternb. }\end{array}$ & Annual & SW and C. Asia & IT & Hygrohalophyte \\
\hline $\begin{array}{l}\text { Halostachys belangeriana } \\
\text { (Moq.) Botsch }\end{array}$ & Chamaephyte & $\begin{array}{l}\text { Central and SW Asia, SE } \\
\text { Europe }\end{array}$ & IT & Hygrohalophyte \\
\hline $\begin{array}{l}\text { Kalidium caspicum (L.) Ung - } \\
\text { Sternb. }\end{array}$ & Chamaephyte & Eurasian & IT & Halophyte \\
\hline $\begin{array}{l}\text { Kalidium wagenitzii (Aellen) } \\
\text { Freitag \& G.Kadereit }\end{array}$ & Chamaephyte & Turkey & IT & Hygrohalophyte \\
\hline $\begin{array}{l}\text { Microcnemum coralloides } \\
\text { (Loscos \& J. Pardo) Buen } \\
\text { subsp. coralloides }\end{array}$ & Annual & Spain & $\mathrm{M}$ & Hygrohalophyte \\
\hline $\begin{array}{l}\text { Microcnemum coralloides } \\
\text { (Loscos \& J. Pardo) Buen } \\
\text { anatolicum Wagenitz }\end{array}$ & Annual & SW Asia & IT & Hygrohalophyte \\
\hline Salicornia procumbens $\mathrm{Sm}$. & Annual & Europe & ES & Hygrohalophyte \\
\hline Salicornia iranica Akhani & Annual & Iran & IT & Hygrohalophyte \\
\hline Salicornia persica Akhani & Annual & Iran, C. Asia, S. Arabia & IT & Hygrohalophyte \\
\hline $\begin{array}{l}\text { Salicornia persica subsp. } \\
\text { rudshurensis Akhani }\end{array}$ & Annual & Iran & IT & Hygrohalophyte \\
\hline Salicornia sp. 18019 & Annual & Turkey & IT & Hygrohalophyte \\
\hline Salicornia $\mathrm{x}$ tashkensis Akhani & Annual & Iran & IT & Hygrohalophyte \\
\hline $\begin{array}{l}\text { Sarcocornia perennis (Mill.) } \\
\text { Scott }\end{array}$ & Chamaephyte & Europe, N. Africa & ES. M & Hygrohalophyte \\
\hline
\end{tabular}


Table 2. Plant taxa and pollen characters investigated in this paper: means and standard deviations based on 50 mature pollen grains for LM characters and 3-5 SEM observations for spinule traits.

\begin{tabular}{|c|c|c|c|c|c|c|c|c|c|c|c|c|c|c|}
\hline है & $\begin{array}{l}\frac{\dot{\Xi}}{0} \\
\overline{0} \\
>\end{array}$ & 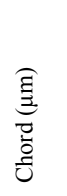 & 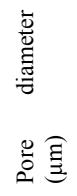 & 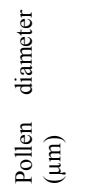 & 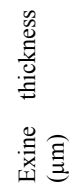 & 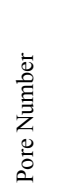 & 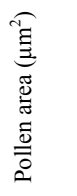 & 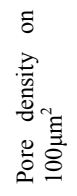 & 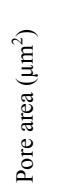 & 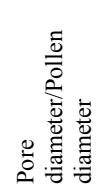 & 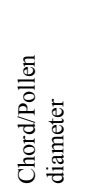 & 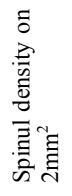 & 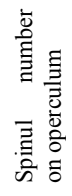 & 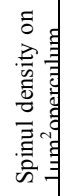 \\
\hline $\begin{array}{l}\text { Arthrocaulon macrosta } \\
\text { chyum (Moric.) } \\
\text { Piirainen \& } \\
\text { G.Kadereit }\end{array}$ & $\begin{array}{l}\text { Dubuis } \\
22.4 .195 \\
2\end{array}$ & $\begin{array}{l}6.25 \\
\pm 0.5\end{array}$ & $\begin{array}{l}2.72 \\
\pm 0.3\end{array}$ & $\begin{array}{l}24.30 \\
\pm 1.5\end{array}$ & $\begin{array}{l}2.27 \\
\pm 0.2\end{array}$ & $\begin{array}{l}36 \pm \\
2.6\end{array}$ & $\begin{array}{l}1861 \\
\pm 239\end{array}$ & $\begin{array}{l}1.98 \\
\pm 0.2\end{array}$ & $\begin{array}{l}5.88 \\
\pm 1.5\end{array}$ & $\begin{array}{l}0.11 \pm \\
0.01\end{array}$ & $\begin{array}{l}0.2576 \pm \\
0.02\end{array}$ & & & \\
\hline $\begin{array}{l}\text { Arthrocaulon macrosta } \\
\text { chyum (Moric.) } \\
\text { Piirainen \& } \\
\text { G.Kadereit }\end{array}$ & $\begin{array}{l}\text { Akhani } \\
16531\end{array}$ & $\begin{array}{l}5.88 \\
\pm 0.5\end{array}$ & $\begin{array}{l}2.43 \\
\pm 0.3\end{array}$ & $\begin{array}{l}27.52 \\
\pm 2\end{array}$ & $\begin{array}{l}1.97 \\
\pm 0.2\end{array}$ & $\begin{array}{l}44 \pm \\
3.2\end{array}$ & $\begin{array}{l}2391 \\
\pm 358\end{array}$ & $\begin{array}{l}1.87 \\
\pm 0.3\end{array}$ & $\begin{array}{l}4.69 \\
\pm 1.1\end{array}$ & $\begin{array}{l}0.09 \pm \\
0.01\end{array}$ & $\begin{array}{l}0.2139 \pm \\
0.01\end{array}$ & $\begin{array}{l}5.8 \pm \\
1\end{array}$ & $\begin{array}{l}13 \pm 1 \\
.4\end{array}$ & 5 \\
\hline $\begin{array}{l}\text { Arthrocaulon macrosta } \\
\text { chyum (Moric.) } \\
\text { Piirainen \& } \\
\text { G.Kadereit }\end{array}$ & $\begin{array}{l}\text { Akhani } \\
16536\end{array}$ & $\begin{array}{l}5.94 \\
\pm 0.5\end{array}$ & $\begin{array}{l}2.74 \\
\pm 0.4\end{array}$ & $\begin{array}{l}25.67 \\
\pm 2\end{array}$ & $\begin{array}{l}2.29 \\
\pm 0.2\end{array}$ & $\begin{array}{l}40 \pm \\
3\end{array}$ & $\begin{array}{l}2081 \\
\pm 327\end{array}$ & $\begin{array}{l}1.98 \\
\pm 0.3\end{array}$ & $\begin{array}{l}6 \pm 1 \\
7\end{array}$ & $\begin{array}{l}0.11 \pm \\
0.01\end{array}$ & $\begin{array}{l}0.2322 \pm \\
0.02\end{array}$ & & & \\
\hline $\begin{array}{l}\text { Arthrocaulon macrosta } \\
\text { chyum (Moric.) } \\
\text { Piirainen \& } \\
\text { G.Kadereit } \\
\end{array}$ & $\begin{array}{l}\text { Barbey } \\
551\end{array}$ & $\begin{array}{l}7.11 \\
\pm 0.6\end{array}$ & $\begin{array}{l}3.06 \\
\pm 0.4\end{array}$ & $\begin{array}{l}26.71 \\
\pm 1.8\end{array}$ & $\begin{array}{l}2.46 \\
\pm 0.2\end{array}$ & $\begin{array}{l}35 \pm \\
2.2\end{array}$ & $\begin{array}{l}2250 \\
\pm 309\end{array}$ & $\begin{array}{l}1.58 \\
\pm 0.2\end{array}$ & $\begin{array}{l}7.45 \\
\pm 1.7\end{array}$ & $\begin{array}{l}0.11 \pm \\
0.01\end{array}$ & $\begin{array}{l}0.2664 \pm \\
0.02\end{array}$ & & & \\
\hline $\begin{array}{l}\text { Halocnemum } \\
\text { strobilaceum (Pall.) M. } \\
\text { Bieb. }\end{array}$ & $\begin{array}{l}\text { Akhani } \\
\& \\
\text { Salimian } \\
15330\end{array}$ & $\begin{array}{l}5.62 \\
\pm 0.2\end{array}$ & $\begin{array}{l}1.53 \\
\pm 0.2\end{array}$ & $\begin{array}{l}20.77 \\
\pm 0.6\end{array}$ & $\begin{array}{l}2.61 \\
\pm 0.3\end{array}$ & $\begin{array}{l}34 \pm \\
1.6\end{array}$ & $\begin{array}{l}1356 \\
\pm 83\end{array}$ & $\begin{array}{l}2.55 \\
\pm 0.2\end{array}$ & $\begin{array}{l}1.86 \\
\pm 0.5\end{array}$ & $\begin{array}{l}0.07 \pm \\
0.01\end{array}$ & $\begin{array}{l}0.2708 \pm \\
0.01\end{array}$ & & & \\
\hline $\begin{array}{l}\text { Halocnemum } \\
\text { strobilaceum (Pall.) M. } \\
\text { Bieb. }\end{array}$ & $\begin{array}{l}\text { Akhani } \\
\text { et al. } \\
18004 \\
\end{array}$ & $\begin{array}{l}5.04 \\
\pm 0.3\end{array}$ & $\begin{array}{l}1.59 \\
\pm 0.2\end{array}$ & $\begin{array}{l}19.69 \\
\pm 0.8\end{array}$ & $\begin{array}{l}2.22 \\
\pm 0.3\end{array}$ & $\begin{array}{l}36 \pm \\
1.5\end{array}$ & $\begin{array}{l}1219 \\
\pm 96\end{array}$ & $\begin{array}{l}3.01 \\
\pm 0.2\end{array}$ & $\begin{array}{l}2.1 \pm \\
0.5\end{array}$ & $\begin{array}{l}0.08 \pm \\
0.01\end{array}$ & $\begin{array}{l}0.2560 \pm \\
0.01\end{array}$ & & & \\
\hline $\begin{array}{l}\text { Halocnemum } \\
\text { strobilaceum (Pall.) M. } \\
\text { Bieb. }\end{array}$ & $\begin{array}{l}\text { Akhani } \\
24152\end{array}$ & $\begin{array}{l}6.08 \\
\pm 0.3\end{array}$ & $\begin{array}{l}2.75 \\
\pm 0.3\end{array}$ & $\begin{array}{l}23.24 \\
\pm 1.7\end{array}$ & $\begin{array}{l}2.03 \\
\pm 0.2\end{array}$ & $\begin{array}{l}36 \pm \\
2\end{array}$ & $\begin{array}{l}1704 \\
\pm 250\end{array}$ & $\begin{array}{l}2.12 \\
\pm 0.2\end{array}$ & $\begin{array}{l}5.97 \\
\pm 1.1\end{array}$ & $\begin{array}{l}0.12 \pm \\
0.01\end{array}$ & $\begin{array}{l}0.2623 \pm \\
0.01\end{array}$ & $\begin{array}{l}16 \pm 0 \\
.8\end{array}$ & $\begin{array}{l}15.3 \\
\pm 3.1\end{array}$ & $\begin{array}{l}8 . \\
8\end{array}$ \\
\hline $\begin{array}{l}\text { Halocnemum } \\
\text { strobilaceum (Pall.) M. } \\
\text { Bieb. }\end{array}$ & $\begin{array}{l}\text { Akhani } \\
7955\end{array}$ & $\begin{array}{l}5.27 \\
\pm 0.4\end{array}$ & $\begin{array}{l}1.50 \\
\pm 0.2\end{array}$ & $\begin{array}{l}19.18 \\
\pm 0.9\end{array}$ & $\begin{array}{l}2.28 \\
\pm 0.3\end{array}$ & $\begin{array}{l}34 \pm \\
1.7\end{array}$ & $\begin{array}{l}1158 \\
\pm 108\end{array}$ & $\begin{array}{l}2.96 \\
\pm 0.3\end{array}$ & $\begin{array}{l}1.77 \\
\pm 0.4\end{array}$ & $\begin{array}{l}0.08 \pm \\
0.01\end{array}$ & $\begin{array}{l}0.2746 \pm \\
0.01\end{array}$ & & & \\
\hline $\begin{array}{l}\text { Halopeplis } \\
\text { amplexicaulis (Vahl) } \\
\text { Ces. \& al. }\end{array}$ & $\begin{array}{l}\text { Dubuis } \\
15.5 .194 \\
9 \\
\end{array}$ & $\begin{array}{l}5.50 \\
\pm 0.6\end{array}$ & $\begin{array}{l}2.46 \\
\pm 0.3\end{array}$ & $\begin{array}{l}21.87 \\
\pm 1.9\end{array}$ & $\begin{array}{l}2.13 \\
\pm 0.2\end{array}$ & $\begin{array}{l}37 \pm \\
2.8\end{array}$ & $\begin{array}{l}1513 \\
\pm 278\end{array}$ & $\begin{array}{l}2.54 \\
\pm 0.5\end{array}$ & $\begin{array}{l}4.75 \\
\pm 1\end{array}$ & $\begin{array}{l}0.11 \pm \\
0.01\end{array}$ & $\begin{array}{l}0.2513 \pm \\
0.02\end{array}$ & & & \\
\hline $\begin{array}{l}\text { Halopeplis } \\
\text { amplexicaulis (Vahl) } \\
\text { Ces. \& al. }\end{array}$ & $\begin{array}{l}\text { Sanchez- } \\
\text { Mata \& } \\
\text { Gavilan } \\
57\end{array}$ & $\begin{array}{l}5.63 \\
\pm 0.4\end{array}$ & $\begin{array}{l}2.49 \\
\pm 0.3\end{array}$ & $\begin{array}{l}21.89 \\
\pm 1.6\end{array}$ & $\begin{array}{l}1.93 \\
\pm 0.2\end{array}$ & $\begin{array}{l}36 \pm \\
2.9\end{array}$ & $\begin{array}{l}1513 \\
\pm 221\end{array}$ & $\begin{array}{l}2.44 \\
\pm 0.3\end{array}$ & $\begin{array}{l}4.87 \\
\pm 1.2\end{array}$ & $\begin{array}{l}0.11 \pm \\
0.01\end{array}$ & $\begin{array}{l}0.2580 \pm \\
0.02\end{array}$ & & & \\
\hline $\begin{array}{l}\text { Halopeplis } \\
\text { perfoliata(Forssk.) } \\
\text { Asch. }\end{array}$ & $\begin{array}{l}\text { Dehghan } \\
\text { i \& \& } \\
\text { Doulatya } \\
\text { ri } 18337\end{array}$ & $\begin{array}{l}5.45 \\
\pm 0.7\end{array}$ & $\begin{array}{l}2.76 \\
\pm 0.4\end{array}$ & $\begin{array}{l}21.36 \\
\pm 2\end{array}$ & $\begin{array}{l}1.83 \\
\pm 0.2\end{array}$ & $\begin{array}{l}37 \pm \\
4.7\end{array}$ & $\begin{array}{l}1444 \\
\pm 266\end{array}$ & $\begin{array}{l}2.65 \\
\pm 0.7\end{array}$ & $\begin{array}{l}5.98 \\
\pm 2.1\end{array}$ & $\begin{array}{l}0.13 \pm \\
0.01\end{array}$ & $\begin{array}{l}0.2552 \pm \\
0.02\end{array}$ & $\begin{array}{l}8.8 \pm \\
1.5\end{array}$ & $\begin{array}{l}30.5 \\
\pm 3.8\end{array}$ & $\begin{array}{l}7 . \\
3\end{array}$ \\
\hline $\begin{array}{l}\text { Halopeplis pygmaea } \\
\text { (Pall.) Bunge ex Ung.- } \\
\text { Sternb. }\end{array}$ & $\begin{array}{l}\text { Akhani } \\
\& \\
\text { Ghobadn } \\
\text { ejhad } \\
15717\end{array}$ & $\begin{array}{l}6.45 \\
\pm 0.3\end{array}$ & $\begin{array}{l}2.1 \pm \\
0.2\end{array}$ & $\begin{array}{l}21.61 \\
\pm 0.6\end{array}$ & $\begin{array}{l}2.97 \\
\pm 0.1\end{array}$ & $\begin{array}{l}31 \pm \\
1.1\end{array}$ & $\begin{array}{l}1468 \\
\pm 84\end{array}$ & $\begin{array}{l}2.13 \\
\pm 0.1\end{array}$ & $\begin{array}{l}3.46 \\
\pm 0.4\end{array}$ & $\begin{array}{l}0.07 \pm \\
0.01\end{array}$ & $\begin{array}{l}0.2983 \pm \\
0.01\end{array}$ & $\begin{array}{l}14.3 \\
\pm 1.3\end{array}$ & $\begin{array}{l}37.5 \\
\pm 2.6\end{array}$ & $\begin{array}{l}6 . \\
8\end{array}$ \\
\hline $\begin{array}{l}\text { Halopeplis pygmaea } \\
\text { (Pall.) Bunge ex Ung.- } \\
\text { Sternb. }\end{array}$ & $\begin{array}{l}\text { Akhani } \\
24170\end{array}$ & $\begin{array}{l}6.77 \\
\pm 0.4\end{array}$ & $\begin{array}{l}2.84 \\
\pm 0.3\end{array}$ & $\begin{array}{l}25.72 \\
\pm 1.7\end{array}$ & $\begin{array}{l}2.35 \\
\pm 0.2\end{array}$ & $\begin{array}{l}35 \pm \\
2.3\end{array}$ & $\begin{array}{l}2086 \\
\pm 279\end{array}$ & $\begin{array}{l}1.72 \\
\pm 0.2\end{array}$ & $\begin{array}{l}6.33 \\
\pm 1.2\end{array}$ & $\begin{array}{l}0.11 \pm \\
0.01\end{array}$ & $\begin{array}{l}0.2639 \pm \\
0.02\end{array}$ & & & \\
\hline $\begin{array}{l}\text { Halopeplis pygmaea } \\
\text { (Pall.) Bunge ex Ung.- } \\
\text { Sternb. }\end{array}$ & $\begin{array}{l}\text { Akhani } \\
5824\end{array}$ & $\begin{array}{l}5.98 \\
\pm 0.4\end{array}$ & $\begin{array}{l}2.2 \pm \\
0.2\end{array}$ & $\begin{array}{l}21.39 \\
\pm 0.9\end{array}$ & $\begin{array}{l}2.51 \\
\pm 0.4\end{array}$ & $\begin{array}{l}33 \pm \\
1.6\end{array}$ & $\begin{array}{l}1439 \\
\pm 119\end{array}$ & $\begin{array}{l}2.33 \\
\pm 0.2\end{array}$ & $\begin{array}{l}3.8 \pm \\
0.6\end{array}$ & $\begin{array}{l}0.07 \pm \\
0.01\end{array}$ & $\begin{array}{l}0.2794 \pm \\
0.01\end{array}$ & & & \\
\hline $\begin{array}{l}\text { Halostachys } \\
\text { belangeriana (Moq.) } \\
\text { Botsch }\end{array}$ & $\begin{array}{l}\text { Akhani } \\
\& \\
\text { Zangui } \\
10055 \\
\end{array}$ & $\begin{array}{l}6.23 \\
\pm 0.3\end{array}$ & $\begin{array}{l}1.82 \\
\pm 0.2\end{array}$ & $\begin{array}{l}23.53 \\
\pm 1\end{array}$ & $\begin{array}{l}2.70 \\
\pm 0.3\end{array}$ & $\begin{array}{l}35 \pm \\
1.9\end{array}$ & $\begin{array}{l}1741 \\
\pm 153\end{array}$ & $\begin{array}{l}2.03 \\
\pm 0.1\end{array}$ & $\begin{array}{l}2.6 \pm \\
0.7\end{array}$ & $\begin{array}{l}0.08 \pm \\
0.01\end{array}$ & $\begin{array}{l}0.2649 \pm \\
1.01\end{array}$ & & & \\
\hline $\begin{array}{l}\text { Halostachys } \\
\text { belangeriana (Moq.) } \\
\text { Botsch }\end{array}$ & $\begin{array}{l}\text { Akhani } \\
\text { 10086-T }\end{array}$ & $\begin{array}{l}5.53 \\
\pm 0.4\end{array}$ & $\begin{array}{l}2.65 \\
\pm 0.3\end{array}$ & $\begin{array}{l}23.51 \\
\pm 1.4\end{array}$ & $\begin{array}{l}2.14 \\
\pm 0.2\end{array}$ & $\begin{array}{l}40 \pm \\
2.6\end{array}$ & $\begin{array}{l}1742 \\
\pm 214\end{array}$ & $\begin{array}{l}2.31 \\
\pm 0.3\end{array}$ & $\begin{array}{l}5.57 \\
\pm 1.1\end{array}$ & $\begin{array}{l}0.11 \pm \\
0.01\end{array}$ & $\begin{array}{l}0.2356 \pm \\
0.02\end{array}$ & & & \\
\hline $\begin{array}{l}\text { Halostachys } \\
\text { belangeriana (Moq.) } \\
\text { Botsch }\end{array}$ & $\begin{array}{l}\text { Akhani } \\
\& \\
\text { Salimian } \\
15434 \\
\end{array}$ & $\begin{array}{l}5.76 \\
\pm 0.3\end{array}$ & $\begin{array}{l}1.84 \\
\pm 0.2\end{array}$ & $\begin{array}{l}22.06 \\
\pm 0.9\end{array}$ & $\begin{array}{l}2.08 \\
\pm 0.2\end{array}$ & $\begin{array}{l}36 \pm \\
1.9\end{array}$ & $\begin{array}{l}1531 \\
\pm 123\end{array}$ & $\begin{array}{l}2.35 \\
\pm 0.2\end{array}$ & $\begin{array}{l}2.68 \\
\pm 0.7\end{array}$ & $\begin{array}{l}0.08 \pm \\
0.01\end{array}$ & $\begin{array}{l}0.2610 \pm \\
0.01\end{array}$ & $\begin{array}{l}12.7 \\
\pm 2.1\end{array}$ & $\begin{array}{l}22.7 \\
\pm 3.1\end{array}$ & $\begin{array}{l}6 . \\
7\end{array}$ \\
\hline $\begin{array}{l}\text { Halostachys } \\
\text { belangeriana (Moq.) } \\
\text { Botsch }\end{array}$ & $\begin{array}{l}\text { Akhani } \\
24324\end{array}$ & $\begin{array}{l}6.25 \\
\pm 0.3\end{array}$ & $\begin{array}{l}2.97 \\
\pm 0.2\end{array}$ & $\begin{array}{l}23.35 \\
\pm 0.9\end{array}$ & $\begin{array}{l}2.18 \\
\pm 0.2\end{array}$ & $\begin{array}{l}35 \pm \\
1.8\end{array}$ & $\begin{array}{l}1714 \\
\pm 135\end{array}$ & $\begin{array}{l}2.04 \\
\pm 0.1\end{array}$ & $\begin{array}{l}6.97 \\
\pm 0.9\end{array}$ & $\begin{array}{l}0.13 \pm \\
0.01\end{array}$ & $\begin{array}{l}0.2681 \pm \\
0.01\end{array}$ & & & \\
\hline $\begin{array}{l}\text { Halostachys } \\
\text { belangeriana (Moq.) }\end{array}$ & $\begin{array}{l}\text { Dehghan } \\
\text { i \& }\end{array}$ & $\begin{array}{l}5.80 \\
\pm 0.3 \\
\end{array}$ & $\begin{array}{l}1.74 \\
\pm 0.3 \\
\end{array}$ & $\begin{array}{l}22.71 \\
\pm 0.8 \\
\end{array}$ & $\begin{array}{l}2.57 \\
\pm 0.3\end{array}$ & $\begin{array}{l}37 \pm \\
1.7 \\
\end{array}$ & $\begin{array}{l}1622 \\
\pm 117\end{array}$ & $\begin{array}{l}2.27 \\
\pm 0.2\end{array}$ & $\begin{array}{l}2.42 \\
\pm 0.7\end{array}$ & $\begin{array}{l}0.08 \pm \\
0.01 \\
\end{array}$ & $\begin{array}{l}0.2553 \pm \\
0.01\end{array}$ & & & \\
\hline
\end{tabular}




\begin{tabular}{|c|c|c|c|c|c|c|c|c|c|c|c|c|c|c|}
\hline Botsch & $\begin{array}{l}\text { Dolatyar } \\
\text { i } 353\end{array}$ & & & & & & & & & & & & & \\
\hline $\begin{array}{l}\text { Halostachys } \\
\text { belangeriana (Moq.) } \\
\text { Botsch }\end{array}$ & $\begin{array}{l}\text { Akhani } \\
4760\end{array}$ & $\begin{array}{l}5.63 \\
\pm 0.3\end{array}$ & $\begin{array}{l}1.80 \\
\pm 0.2\end{array}$ & $\begin{array}{l}21.89 \\
\pm 0.6\end{array}$ & $\begin{array}{l}2.39 \\
\pm 0.3\end{array}$ & $\begin{array}{l}36 \pm \\
1.7\end{array}$ & $\begin{array}{l}1505 \\
\pm 82\end{array}$ & $\begin{array}{l}2.42 \\
\pm 0.2\end{array}$ & $\begin{array}{l}2.57 \\
\pm 0.7\end{array}$ & $\begin{array}{l}0.08 \pm \\
0.01\end{array}$ & $\begin{array}{l}0.2573 \pm \\
0.01\end{array}$ & & & \\
\hline $\begin{array}{l}\text { Halostachys } \\
\text { belangeriana (Moq.) } \\
\text { Botsch }\end{array}$ & $\begin{array}{l}\text { Dehghan } \\
\text { i } 7118\end{array}$ & $\begin{array}{l}6.24 \\
\pm 0.4\end{array}$ & $\begin{array}{l}2.92 \\
\pm 0.2\end{array}$ & $\begin{array}{l}27.29 \\
\pm 1.8\end{array}$ & $\begin{array}{l}2.32 \\
\pm 0.2\end{array}$ & $\begin{array}{l}41 \pm \\
2.4\end{array}$ & $\begin{array}{l}2348 \\
\pm 312\end{array}$ & $\begin{array}{l}1.76 \\
\pm 0.2\end{array}$ & $\begin{array}{l}6.74 \\
\pm 1.1\end{array}$ & $\begin{array}{l}0.11 \pm \\
0.01\end{array}$ & $\begin{array}{l}0.2293 \pm \\
0.01\end{array}$ & & & \\
\hline $\begin{array}{l}\text { Kalidium caspicum (L.) } \\
\text { Ung -Sternb. }\end{array}$ & $\begin{array}{l}\text { Akhani } \\
12120\end{array}$ & $\begin{array}{l}5.57 \\
\pm 0.3 \\
\end{array}$ & $\begin{array}{l}2.1 \pm \\
02\end{array}$ & $\begin{array}{l}20.15 \\
\pm 0.6 \\
\end{array}$ & $\begin{array}{l}2.26 \\
\pm 0.3 \\
\end{array}$ & $\begin{array}{l}34 \pm \\
1.6 \\
\end{array}$ & $\begin{array}{l}1275 \\
\pm 74\end{array}$ & $\begin{array}{l}2.65 \\
\pm 0.2 \\
\end{array}$ & $\begin{array}{l}3.46 \\
\pm 0.6 \\
\end{array}$ & $\begin{array}{l}0.08 \pm \\
0.01 \\
\end{array}$ & $\begin{array}{l}0.2766 \pm \\
0.01\end{array}$ & $\begin{array}{l}10.3 \\
\pm 1.3\end{array}$ & $\begin{array}{l}12.5 \\
\pm 1\end{array}$ & $\begin{array}{l}6 . \\
8\end{array}$ \\
\hline $\begin{array}{l}\text { Kalidium caspicum (L.) } \\
\text { Ung -Sternb. }\end{array}$ & $\begin{array}{l}\text { Akhani } \\
16500\end{array}$ & $\begin{array}{l}5.56 \\
\pm 0.3 \\
\end{array}$ & $\begin{array}{l}2.3 \pm \\
0.2 \\
\end{array}$ & $\begin{array}{l}20.15 \\
\pm 0.6 \\
\end{array}$ & $\begin{array}{l}2.26 \\
\pm 0.2 \\
\end{array}$ & $\begin{array}{l}34 \pm \\
1.3 \\
\end{array}$ & $\begin{array}{l}1276 \\
\pm 83\end{array}$ & $\begin{array}{l}2.66 \\
\pm 0.2 \\
\end{array}$ & $\begin{array}{l}4.15 \\
\pm 0.7 \\
\end{array}$ & $\begin{array}{l}0.08 \pm \\
0.01 \\
\end{array}$ & $\begin{array}{l}0.2759 \pm \\
0.01\end{array}$ & & & \\
\hline $\begin{array}{l}\text { Kalidium caspicum (L.) } \\
\text { Ung -Sternb. }\end{array}$ & $\begin{array}{l}\text { Akhani } \\
24164\end{array}$ & $\begin{array}{l}6.02 \\
\pm 0.8 \\
\end{array}$ & $\begin{array}{l}2.91 \\
\pm 0.5 \\
\end{array}$ & $\begin{array}{l}22.90 \\
\pm 1.5 \\
\end{array}$ & $\begin{array}{l}2.11 \\
\pm 0.2 \\
\end{array}$ & $\begin{array}{l}37 \pm \\
9.8 \\
\end{array}$ & $\begin{array}{l}1654 \\
\pm 228\end{array}$ & $\begin{array}{l}2.23 \\
\pm 0.6 \\
\end{array}$ & $\begin{array}{l}6.85 \\
\pm 1.2 \\
\end{array}$ & $\begin{array}{l}0.13 \pm \\
0.01\end{array}$ & $\begin{array}{l}0.2637 \pm \\
0.04\end{array}$ & & & \\
\hline $\begin{array}{l}\text { Kalidium wagenitzii } \\
\text { (Aellen) Freitag \& } \\
\text { G.Kadereit }\end{array}$ & $\begin{array}{l}\text { Akhani } \\
\text { et al. } \\
18001\end{array}$ & $\begin{array}{l}5.34 \\
\pm 0.3\end{array}$ & $\begin{array}{l}2.20 \\
\pm 0.2\end{array}$ & $\begin{array}{l}18.16 \\
\pm 1\end{array}$ & $\begin{array}{l}1.82 \\
\pm 0.2\end{array}$ & $\begin{array}{l}32 \pm \\
2\end{array}$ & $\begin{array}{l}1039 \\
\pm 118\end{array}$ & $\begin{array}{l}3.07 \\
\pm 0.3\end{array}$ & $\begin{array}{l}3.85 \\
\pm 0.8\end{array}$ & $\begin{array}{l}0.12 \pm \\
0.01\end{array}$ & $\begin{array}{l}0.2948 \pm \\
0.02\end{array}$ & $\begin{array}{l}11.2 \\
\pm 1.3\end{array}$ & $\begin{array}{l}13.5 \\
\pm 2.1\end{array}$ & $\begin{array}{l}6 . \\
3\end{array}$ \\
\hline $\begin{array}{l}\text { Microcnemum } \\
\text { coralloides (Loscos\& } \\
\text { J. Pardo) Buen subsp. } \\
\text { coralloides }\end{array}$ & $\begin{array}{l}\text { Lores et } \\
\text { Bernal } \\
6-9.1872\end{array}$ & $\begin{array}{l}6.74 \\
\pm 0.6\end{array}$ & $\begin{array}{l}2.40 \\
\pm 0.2\end{array}$ & $\begin{array}{l}25.91 \\
\pm 1.9\end{array}$ & $\begin{array}{l}2.12 \\
\pm 0.2\end{array}$ & $\begin{array}{l}36 \pm \\
2.5\end{array}$ & $\begin{array}{l}2120 \\
\pm 317\end{array}$ & $\begin{array}{l}1.73 \\
\pm 0.3\end{array}$ & $\begin{array}{l}4.56 \\
\pm 0.9\end{array}$ & $\begin{array}{l}0.09 \pm \\
0.01\end{array}$ & $\begin{array}{l}0.2604 \pm \\
0.02 \pm\end{array}$ & & & \\
\hline $\begin{array}{l}\text { Microcnemum } \\
\text { coralloides (Loscos\& } \\
\text { J. Pardo) Buen subsp } \\
\text { anatolicum } \text { Wagenitz }\end{array}$ & $\begin{array}{l}\text { Akhani } \\
24319\end{array}$ & $\begin{array}{l}6.86 \\
\pm 0.5\end{array}$ & $\begin{array}{l}2.85 \\
\pm 0.2\end{array}$ & $\begin{array}{l}25.31 \\
\pm 1.2\end{array}$ & $\begin{array}{l}2.07 \\
\pm 0.1\end{array}$ & $\begin{array}{l}34 \pm \\
2.6\end{array}$ & $\begin{array}{l}2016 \\
\pm 196\end{array}$ & $\begin{array}{l}1.72 \\
\pm 0.2\end{array}$ & $\begin{array}{l}6.42 \\
\pm 1\end{array}$ & $\begin{array}{l}0.11 \pm \\
0.01\end{array}$ & $\begin{array}{l}0.2714 \pm \\
0.02\end{array}$ & $\begin{array}{l}14 \pm 1 \\
.7\end{array}$ & $\begin{array}{l}21.7 \\
\pm 6.8\end{array}$ & $\begin{array}{l}12 \\
.1\end{array}$ \\
\hline $\begin{array}{l}\text { Salicornia procumbens } \\
\text { Sm. }\end{array}$ & $\begin{array}{l}\text { Akhani } \\
18494\end{array}$ & $\begin{array}{l}5.67 \\
\pm 0.2\end{array}$ & $\begin{array}{l}2.00 \\
\pm 0.1\end{array}$ & $\begin{array}{l}27.88 \\
\pm 0.8\end{array}$ & $\begin{array}{l}2.52 \\
\pm 0.3\end{array}$ & $\begin{array}{l}46 \pm \\
1.5\end{array}$ & $\begin{array}{l}2442 \\
\pm 146\end{array}$ & $\begin{array}{l}1.89 \\
\pm 0.1\end{array}$ & $\begin{array}{l}3.13 \\
\pm 0.4\end{array}$ & $\begin{array}{l}0.07 \pm \\
0.01\end{array}$ & $\begin{array}{l}0.2033 \pm \\
0.01\end{array}$ & $\begin{array}{l}10.8 \\
\pm 1\end{array}$ & $\begin{array}{r}29.5 \\
\pm 3.1\end{array}$ & $\begin{array}{l}6 . \\
4\end{array}$ \\
\hline $\begin{array}{l}\text { Salicornia iranica } \\
\text { Akhani }\end{array}$ & $\begin{array}{l}\text { Akhani } \\
\& \\
\text { Ghobadn } \\
\text { ejhad } \\
15721\end{array}$ & $\begin{array}{l}5.46 \\
\pm 0.4\end{array}$ & $\begin{array}{l}1.87 \\
\pm 0.2\end{array}$ & $\begin{array}{l}24.81 \\
\pm 1\end{array}$ & $\begin{array}{l}2.40 \\
\pm 0.3\end{array}$ & $\begin{array}{l}43 \pm \\
2.6\end{array}$ & $\begin{array}{l}1935 \\
\pm 139\end{array}$ & $\begin{array}{l}2.21 \\
\pm 0.2\end{array}$ & $\begin{array}{l}2.76 \\
\pm 0.6\end{array}$ & $\begin{array}{l}0.08 \pm \\
0.01\end{array}$ & $\begin{array}{l}0.2201 \pm \\
0.01\end{array}$ & $\begin{array}{l}9.3 \pm \\
1.7\end{array}$ & $\begin{array}{l}17.3 \\
\pm 1.8\end{array}$ & $\begin{array}{l}4 . \\
3\end{array}$ \\
\hline $\begin{array}{l}\text { Salicornia } \\
\text { persicaAkhani }\end{array}$ & $\begin{array}{l}\text { Akhani } \\
\& \\
\text { Ghobadn } \\
\text { ejhad } \\
15667\end{array}$ & $\begin{array}{l}4.81 \\
\pm 0.2\end{array}$ & $\begin{array}{l}1.77 \\
\pm 0.2\end{array}$ & $\begin{array}{l}22.21 \\
\pm 0.7\end{array}$ & $\begin{array}{l}2.12 \\
\pm 0.2\end{array}$ & $\begin{array}{l}43 \pm \\
2\end{array}$ & $\begin{array}{l}1550 \\
\pm 99\end{array}$ & $\begin{array}{l}2.80 \\
\pm 0.2\end{array}$ & $\begin{array}{l}2.5 \pm \\
0.2\end{array}$ & $\begin{array}{l}0.08 \pm \\
0.01\end{array}$ & $\begin{array}{l}0.2166 \pm \\
0.01\end{array}$ & & & \\
\hline $\begin{array}{l}\text { Salicornia persica } \\
\text { Akhani }\end{array}$ & $\begin{array}{l}\text { Akhani } \\
\& \\
\text { Ghobadn } \\
\text { ezhad } \\
15670\end{array}$ & $\begin{array}{l}6.38 \\
\pm 0.3\end{array}$ & $\begin{array}{l}1.85 \\
\pm 0.2\end{array}$ & $\begin{array}{l}25.94 \\
\pm 1\end{array}$ & $\begin{array}{l}2.69 \\
\pm 0.3\end{array}$ & $\begin{array}{l}38 \pm \\
1.6\end{array}$ & $\begin{array}{l}2115 \\
\pm 158\end{array}$ & $\begin{array}{l}1.81 \\
\pm 0.1\end{array}$ & $\begin{array}{l}2.71 \\
\pm 0.6\end{array}$ & $\begin{array}{l}0.07 \pm \\
0.01\end{array}$ & $\begin{array}{l}0.2459 \pm \\
0.01\end{array}$ & & & \\
\hline $\begin{array}{l}\text { Salicornia persica } \\
\text { Akhani }\end{array}$ & $\begin{array}{l}\text { Akhani } \\
\& \\
\text { Ghobadn } \\
\text { ezhad } \\
15671\end{array}$ & $\begin{array}{l}5.41 \\
\pm 0.3\end{array}$ & $\begin{array}{l}1.92 \\
\pm 0.2\end{array}$ & $\begin{array}{l}22.97 \\
\pm 0.9\end{array}$ & $\begin{array}{l}3.17 \\
\pm 4.5\end{array}$ & $\begin{array}{l}40 \pm \\
2.2\end{array}$ & $\begin{array}{l}1659 \\
\pm 127\end{array}$ & $\begin{array}{l}2.41 \\
\pm 0.2\end{array}$ & $\begin{array}{l}2.92 \\
\pm 0.5\end{array}$ & $\begin{array}{l}0.08 \pm \\
0.01\end{array}$ & $\begin{array}{l}0.2356 \pm \\
0.01\end{array}$ & & & \\
\hline $\begin{array}{l}\text { Salicornia persica } \\
\text { Akhani }\end{array}$ & $\begin{array}{l}\text { Akhani } \\
\& \\
\text { Ghobadn } \\
\text { ezhad } \\
15720\end{array}$ & $\begin{array}{l}6.15 \\
\pm 0.3\end{array}$ & $\begin{array}{l}2.01 \\
\pm 0.2\end{array}$ & $\begin{array}{l}26.41 \\
\pm 0.8\end{array}$ & $\begin{array}{l}2.50 \\
\pm 0.3\end{array}$ & $\begin{array}{l}40 \pm \\
1.8\end{array}$ & $\begin{array}{l}2192 \\
\pm 137\end{array}$ & $\begin{array}{l}1.84 \\
\pm 0.1\end{array}$ & $\begin{array}{l}3.18 \\
\pm 0.7\end{array}$ & $\begin{array}{l}0.08 \pm \\
0.01\end{array}$ & $\begin{array}{l}0.2328 \pm \\
0.01\end{array}$ & $\begin{array}{l}7.2 \pm \\
1.5\end{array}$ & $\begin{array}{l}23.6 \\
\pm 2.7\end{array}$ & $\begin{array}{l}5 . \\
9\end{array}$ \\
\hline $\begin{array}{l}\text { Salicornia persica } \\
\text { subsp. rudshurensis } \\
\text { Akhani }\end{array}$ & $\begin{array}{l}\text { Akhani } \\
17423\end{array}$ & $\begin{array}{l}5.70 \\
\pm 0.5\end{array}$ & $\begin{array}{l}2.06 \\
\pm 0.2\end{array}$ & $\begin{array}{l}26.32 \\
\pm 1.9\end{array}$ & $\begin{array}{l}2.49 \\
\pm 0.3\end{array}$ & $\begin{array}{l}43 \pm \\
2.4\end{array}$ & $\begin{array}{l}2187 \\
\pm 326\end{array}$ & $\begin{array}{l}2.02 \\
\pm 0.3\end{array}$ & $\begin{array}{l}3.35 \\
\pm 0.6\end{array}$ & $\begin{array}{l}0.08 \pm \\
0.01\end{array}$ & $\begin{array}{l}0.2165 \pm \\
0.01\end{array}$ & & & \\
\hline $\begin{array}{l}\text { Salicornia persica } \\
\text { subsp. rudshurensis } \\
\text { Akhani }\end{array}$ & $\begin{array}{l}\text { Akhani } \\
17319\end{array}$ & $\begin{array}{l}5.65 \\
\pm 0.4\end{array}$ & $\begin{array}{l}1.91 \\
\pm 0.2\end{array}$ & $\begin{array}{l}27.03 \\
\pm 1\end{array}$ & $\begin{array}{l}2.49 \\
\pm 0.3\end{array}$ & $\begin{array}{l}45 \pm \\
1.9\end{array}$ & $\begin{array}{l}2296 \\
\pm 170\end{array}$ & $\begin{array}{l}1.97 \\
\pm 0.2\end{array}$ & $\begin{array}{l}2.88 \\
\pm 0.6\end{array}$ & $\begin{array}{l}0.07 \pm \\
0.01\end{array}$ & $\begin{array}{l}0.2088 \pm \\
0.01\end{array}$ & & & \\
\hline Salicornia sp. 18019 & $\begin{array}{l}\text { Akhaniet } \\
\text { al. } \\
18019 \\
\end{array}$ & $\begin{array}{l}5.06 \\
\pm 0.3\end{array}$ & $\begin{array}{l}1.77 \\
\pm 0.2\end{array}$ & $\begin{array}{l}23.97 \\
\pm 0.9\end{array}$ & $\begin{array}{l}2.22 \\
\pm 0.3\end{array}$ & $\begin{array}{l}44 \pm \\
1.7\end{array}$ & $\begin{array}{l}1806 \\
\pm 134\end{array}$ & $\begin{array}{l}2.47 \\
\pm 0.2\end{array}$ & $\begin{array}{l}2.49 \\
\pm 0.7\end{array}$ & $\begin{array}{l}0.07 \pm \\
0.01\end{array}$ & $\begin{array}{l}0.2109 \pm \\
0.01\end{array}$ & & & \\
\hline Salicornia sp. 18020 & $\begin{array}{l}\text { Akhani } \\
\text { et al. } \\
18020\end{array}$ & $\begin{array}{l}5.01 \\
\pm 0.2\end{array}$ & $\begin{array}{l}1.93 \\
\pm 0.2\end{array}$ & $\begin{array}{l}23.60 \\
\pm 0.7\end{array}$ & $\begin{array}{l}2.26 \\
\pm 0.3\end{array}$ & $\begin{array}{l}44 \pm \\
1.8\end{array}$ & $\begin{array}{l}1750 \\
\pm 105\end{array}$ & $\begin{array}{l}2.53 \\
\pm 0.2\end{array}$ & $\begin{array}{l}2.93 \\
\pm 0.5\end{array}$ & $\begin{array}{l}0.08 \pm \\
0.01\end{array}$ & $\begin{array}{l}0.2121 \pm \\
0.01\end{array}$ & & & \\
\hline $\begin{array}{l}\text { Salicornia } \mathrm{x} \text { tashkensis } \\
\text { Akhani }\end{array}$ & $\begin{array}{l}\text { Akhani } \\
\& \\
\text { Ghobadn } \\
\text { ejhad } \\
15722\end{array}$ & $\begin{array}{l}5.85 \\
\pm 0.6\end{array}$ & $\begin{array}{l}2.00 \\
\pm 0.1\end{array}$ & $\begin{array}{l}25.11 \\
\pm 1.4\end{array}$ & $\begin{array}{l}2.38 \\
\pm 0.4\end{array}$ & $\begin{array}{l}40 \pm \\
2.4\end{array}$ & $\begin{array}{l}1986 \\
\pm 233\end{array}$ & $\begin{array}{l}2.06 \\
\pm 0.3\end{array}$ & $\begin{array}{l}3.13 \\
\pm 0.4\end{array}$ & $\begin{array}{l}0.08 \pm \\
0.01\end{array}$ & $\begin{array}{l}0.2326 \pm \\
0.01\end{array}$ & & & \\
\hline $\begin{array}{l}\text { Sarcocornia perennis } \\
\text { (Mill.) Scott }\end{array}$ & $\begin{array}{l}\text { Bouby } \\
4951\end{array}$ & $\begin{array}{l}5.59 \\
\pm 0.4\end{array}$ & $\begin{array}{l}2.86 \\
\pm 0.4\end{array}$ & $\begin{array}{l}27.62 \\
\pm 2.5\end{array}$ & $\begin{array}{l}2.31 \\
\pm 0.2\end{array}$ & $\begin{array}{l}46 \pm \\
3.8\end{array}$ & $\begin{array}{l}2414 \\
\pm 415\end{array}$ & $\begin{array}{l}1.97 \\
\pm 0.3\end{array}$ & $\begin{array}{l}8.27 \\
\pm 1.6\end{array}$ & $\begin{array}{l}0.10 \pm \\
0.01\end{array}$ & $\begin{array}{l}0.2032 \pm \\
0.02\end{array}$ & $\begin{array}{l}10 \pm 1 \\
.4\end{array}$ & $\begin{array}{l}21.7 \\
\pm 2.5\end{array}$ & $\begin{array}{l}5 . \\
9\end{array}$ \\
\hline $\begin{array}{l}\text { Sarcocornia perennis } \\
\text { (Mill.) Scott. }\end{array}$ & $\begin{array}{l}\text { Guillon } \\
3895\end{array}$ & $\begin{array}{l}6.77 \\
\pm 0.7\end{array}$ & $\begin{array}{l}3.20 \\
\pm 0.6\end{array}$ & $\begin{array}{l}36.13 \\
\pm 3.1\end{array}$ & $\begin{array}{l}2.81 \\
\pm 0.3\end{array}$ & $\begin{array}{l}51 \pm \\
7.7\end{array}$ & $\begin{array}{l}4128 \\
\pm 736\end{array}$ & $\begin{array}{l}1.26 \\
\pm 0.3\end{array}$ & $\begin{array}{l}6.53 \\
\pm 1.1\end{array}$ & $\begin{array}{l}0.09 \pm \\
0.01\end{array}$ & $\begin{array}{l}0.1876 \pm \\
0.02\end{array}$ & & & \\
\hline
\end{tabular}



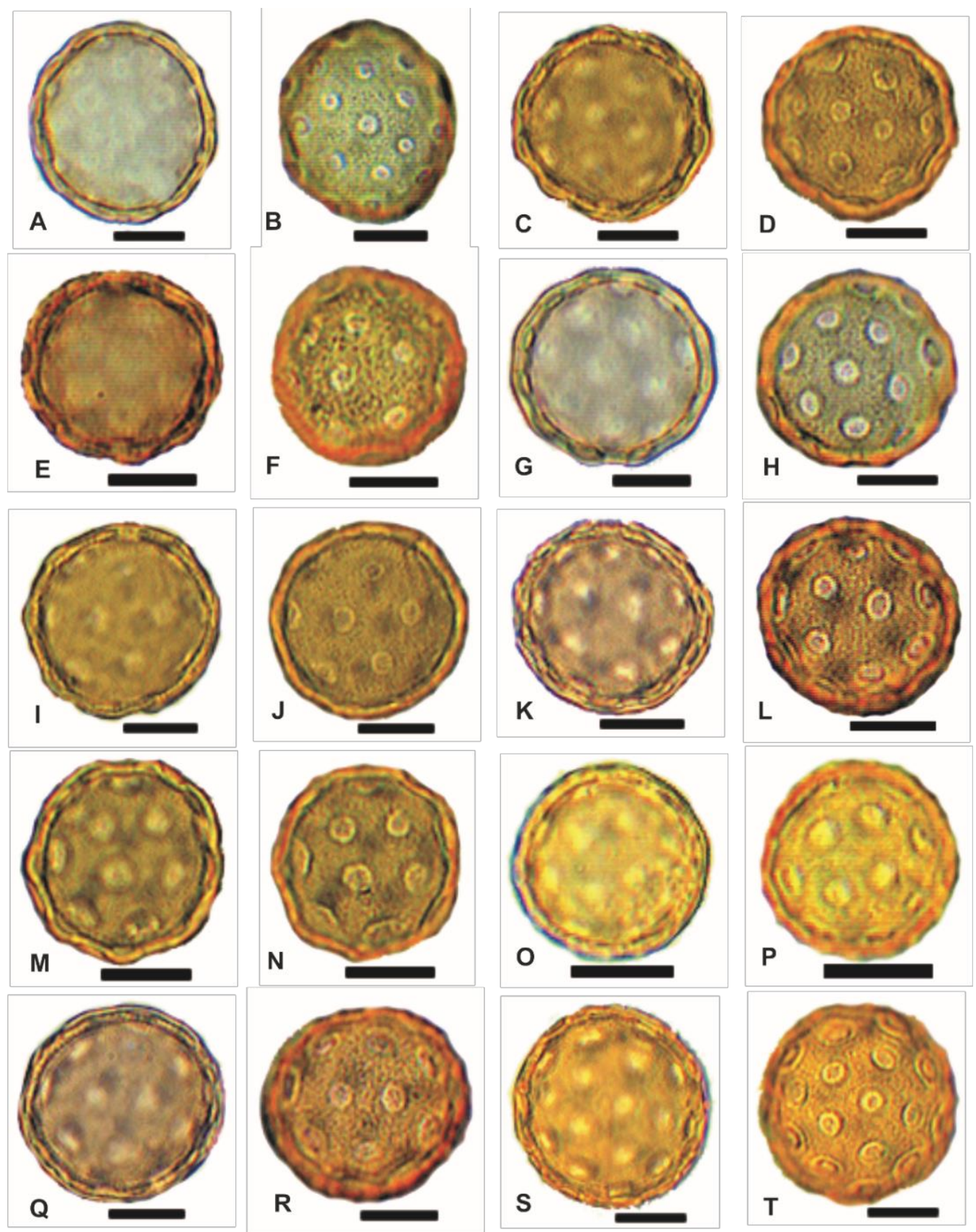

Fig. 1. Light microscope images of pollen grains of selected Salicornioideae taxa in two focal levels to show both exine structures and pore characteristics. Scale bar $=10 \mu \mathrm{m}$. A, B.

Arthrocaulon macrostachyum (Akhani 16531); C, D. Halocnemum strobilaceum (Akhani 24152); E, F. Halopeplis amplexicaulis (Sanchez- Mata \& Gavilan 57); G, H. Halopeplis perfoliata (Dehghani \& Doulatyari 18337); I, J. Halopeplis pygmaea (Akhani 24170); K, L. Halostachys belangeriana (Akhani 24324); M, N. Kalidium capsicum (Akhani 24164); O, P. Kalidium wagenitzii (Akhani et al. 18001); Q, R. Microcnemum coralloides (Akhani 24319); S, T. Salicornia procumbens (Akhani 18494) 

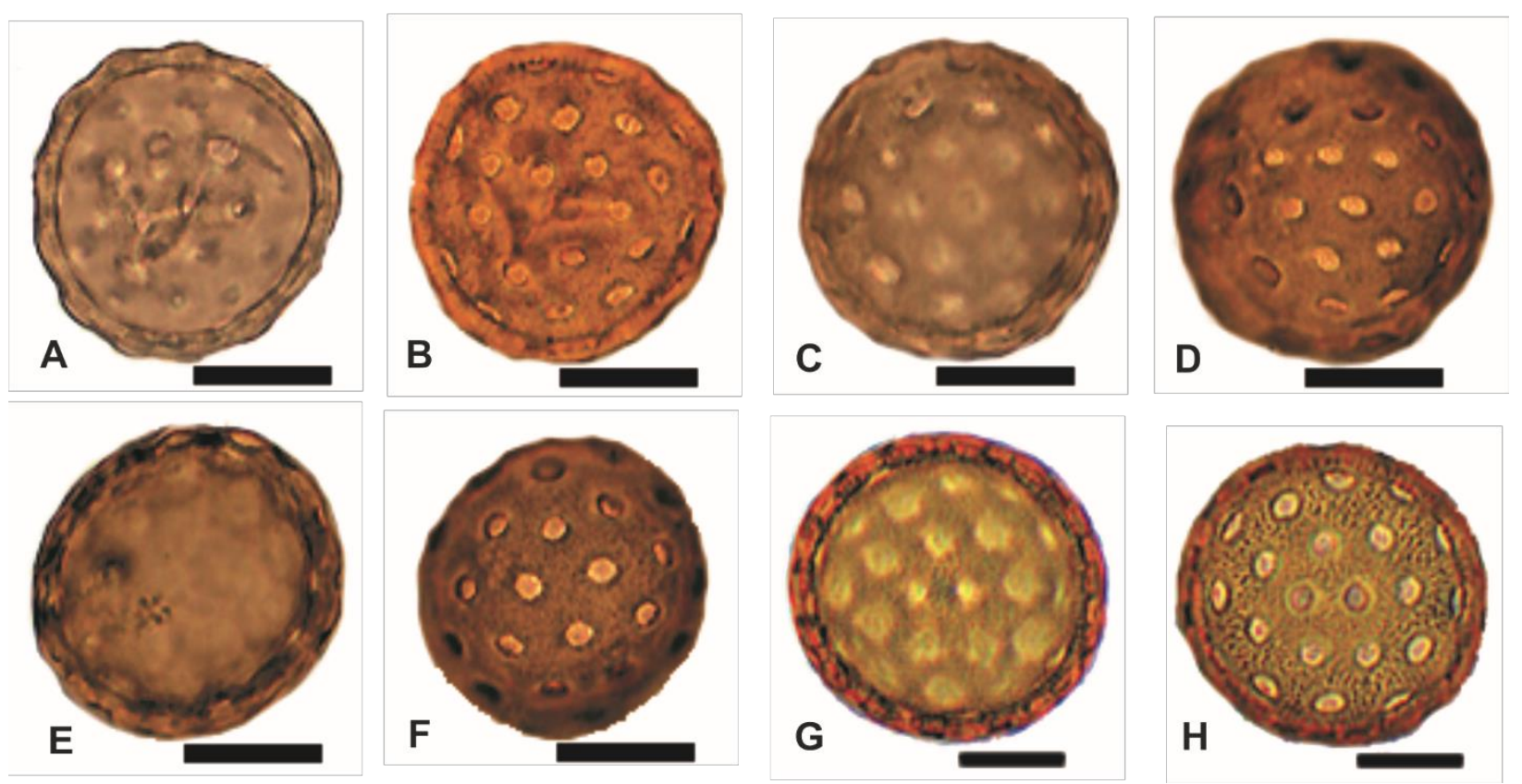

Fig. 2. Light microscope images of pollen grains of selected Salicornioideae taxa in two focal levels to show both exine structures and pore characteristics. Scale bar $=10 \mu \mathrm{m}$.A, B. Salicornia iranica (Akhani \& Ghobadnejhad 15721); C, D. Salicornia persica (Akhani \& Ghobadnezhad 15720); E, F. Salicornia sp (Akhani et al. 18019; G, H. Sarcocornia perennis (Bouby 4951) 

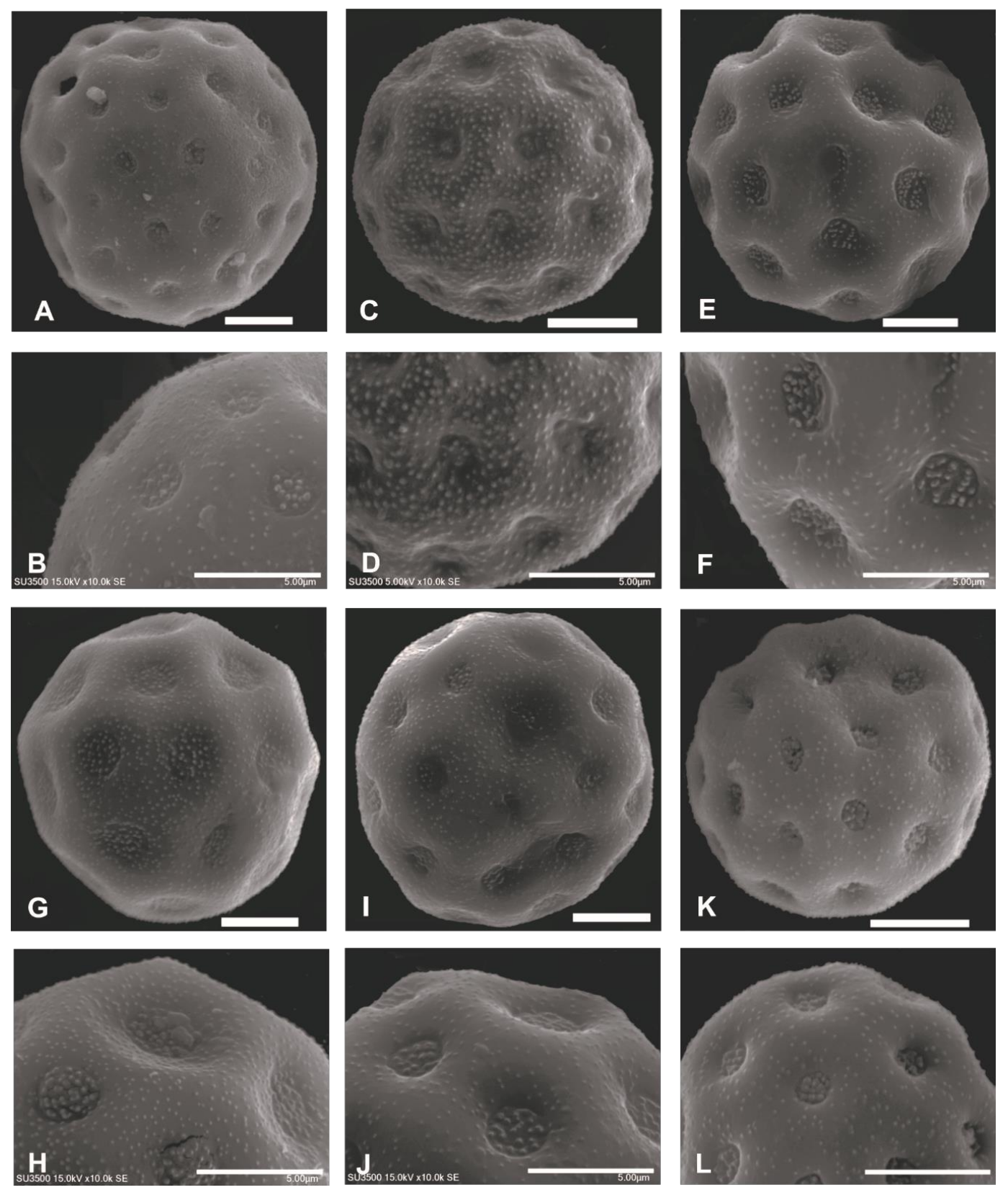

Fig. 3. SEM micrographs of selected pollen grains of Salicornioideae. Scale bar $=5 \mu \mathrm{m}$. A, B. Arthrocaulon macrostachyum (Akhani 16531); C, D. Halocnemum strobilaceum (Akhani 24152); E, F. Halopeplis perfoliata (Dehghani \& Doulatyari 18337); G, H. Halopeplis pygmaea (Akhani \& Ghobadnejhad 15717); I, J. Halostachis belangeriana (Akhani \& Salimian 15434); K, L. Kalidium capsicum (Akhani 12120) 

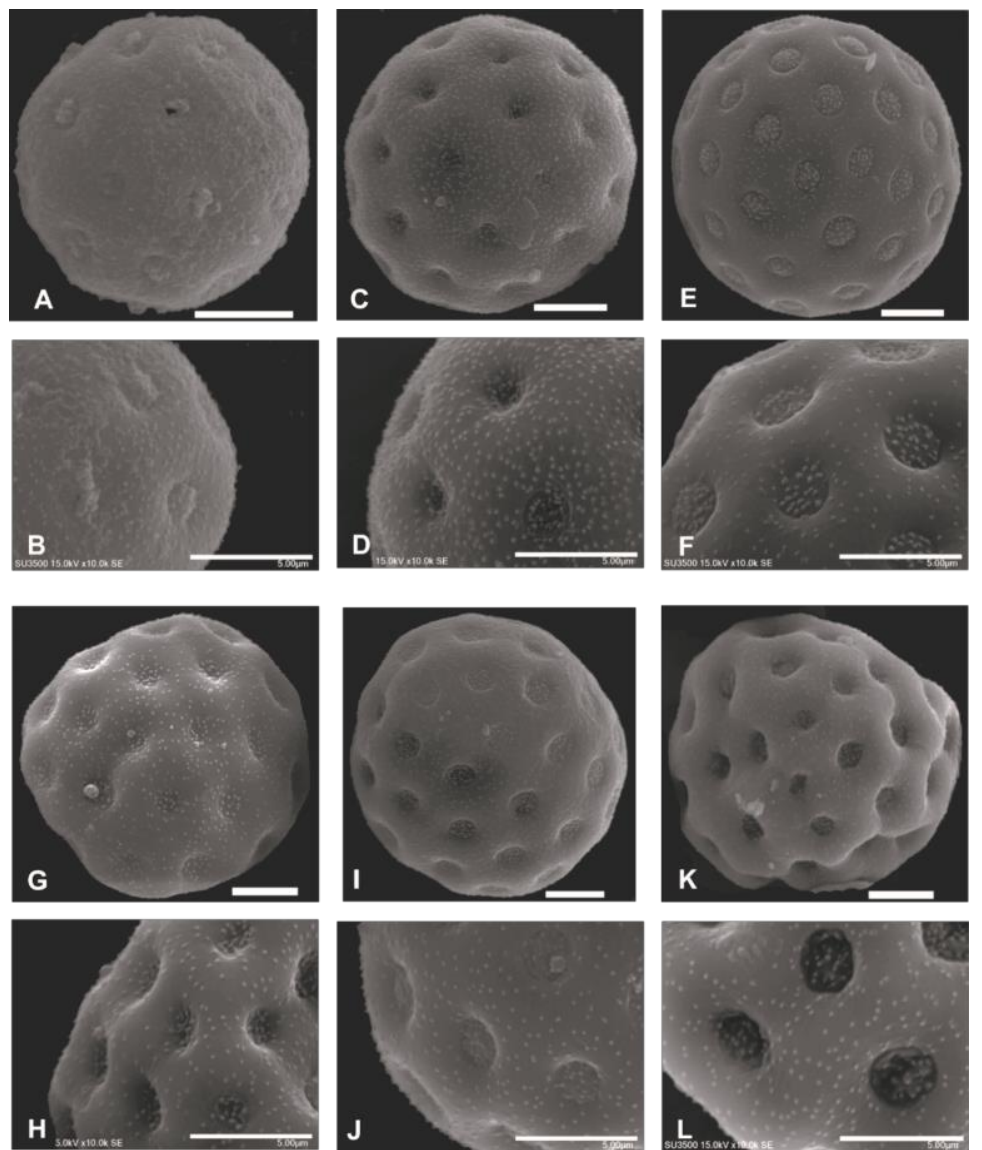

Fig. 4. SEM micrographs of selected pollen grains of Salicornioideae. Scale bar $=5 \mu \mathrm{m}$. A, B.

Kalidium wagenitzii (Akhani et al. 18001); C, D. Microcnemum coralloides (Akhani 24319); E, F. Salicornia procumbens (Akhani 18494); G, H. Salicornia iranica (Akhani \& Ghobadnejhad 15721); I, J. Salicornia persica (Akhani \& Ghobadnezhad 15720); K, L. Sarcocornia perennis (Bouby 4951) 


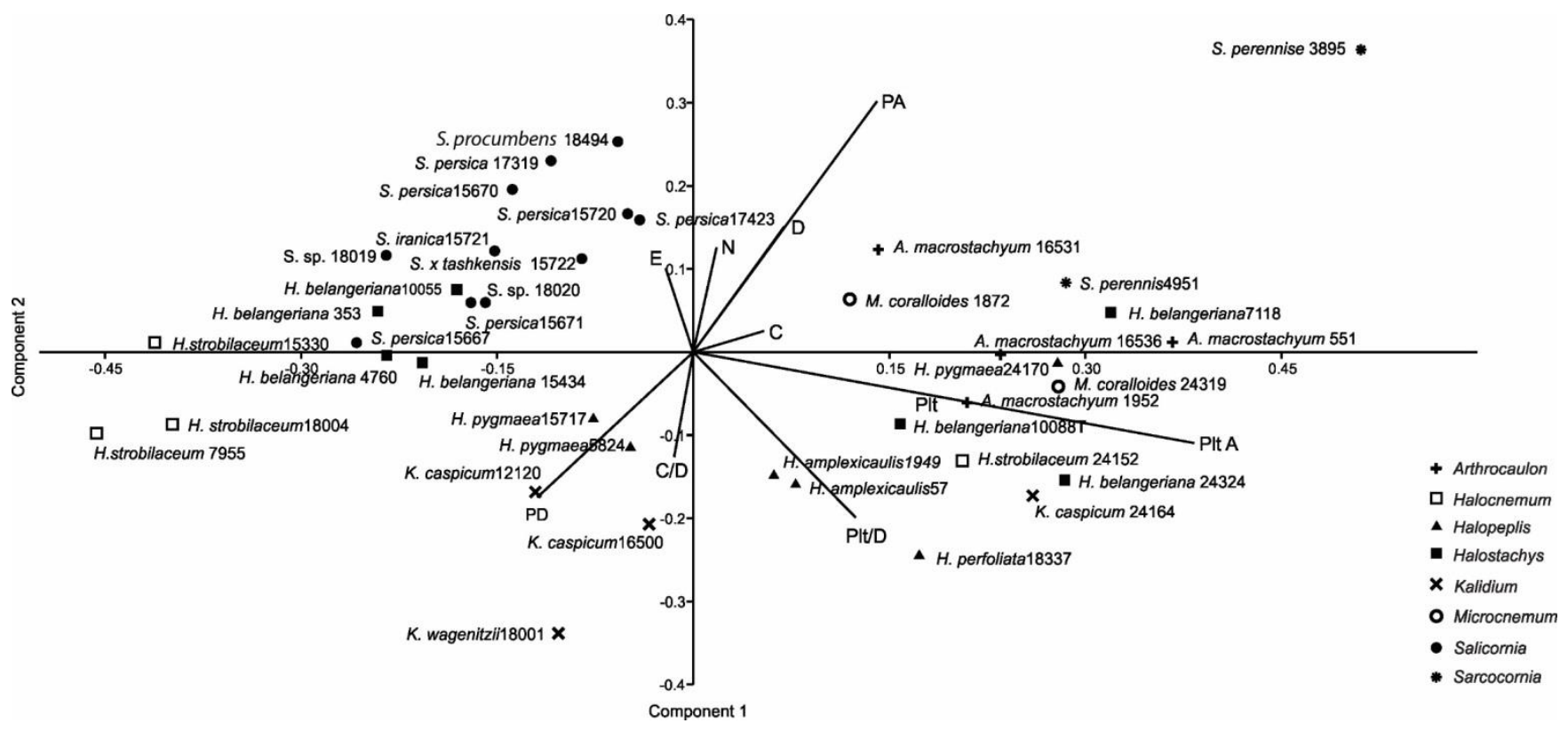

Fig. 5. Principal Components Analysis (PCA) biplot for pollen data of studied samples of Salicornioideae (Chenopodiaceae). PCA axes 1 and 2 explain respectively $67.99 \%$ and $27.11 \%$ of the total variance. $\mathrm{C}=$ chord, $\mathrm{C} / \mathrm{D}=$ chord/pollen diameter, $\mathrm{D}=$ pollen diameter, $\mathrm{E}=$ exine, $\mathrm{N}=$ pore number, $\mathrm{PA}=$ pollen area, $\mathrm{PD}=$ pore density, $\mathrm{Plt}=$ pore diameter, $\mathrm{Plt} \mathrm{A}=$ pore area, $\mathrm{Plt} / \mathrm{D}=$ pore diameter/ pollen diameter. 